\title{
Water chemistry and trophic evaluation of Lake Albano (Central Italy): a four year water monitoring study
}

\author{
Neil T.W. ELLWOOD*, Patrizia ALBERTANO'), Rosa GALVEZ ${ }^{2)}$, Renato FUNICIELLO and Rosario MOSELLO ${ }^{3)}$ \\ Dipartimento di Scienze Geologiche, Università Roma Tre, Largo San Leonardo Murialdo 1, 000146 Rome, Italy \\ ${ }^{1)}$ Dipartimento di Biologia, Università di Tor Vergata, Via della Ricerca Scientifica 1, 00173 Rome, Italy \\ ${ }^{2)}$ Department of Civil Engineering, Adrien Pouliot Building, Laval University, Quebec, G1K 7P7, Canada \\ ${ }^{3)}$ CNR Istituto per lo Studio degli Ecosistemi, Largo Tonolli 50, 28922 Verbania Pallanza, Italy \\ *e-mail corresponding author: ellwood@uniroma3.it
}

\begin{abstract}
The crater lake Lake Albano is an increasingly diminishing water resource in terms of volume, the lake level has dropped more than four meters since the 1960s, and water quality resulting from elevated levels of nitrogen and phosphorus. The area of the lake, and the volcano as a whole, is also considered to be geologically hazardous due to continual shallow seismic activity, gaseous emissions and hydrothermal activity. Therefore, most research has been focussed on the geological aspects of the Albano lake system, whilst long-term limnological studies have been lacking. A meromictic classification was given to the lake, but this was based on one year studies of the surface water only. Presented and discussed are the results of a water chemistry and biological study of the full depth profile of Lake Albano from 2004 to 2008. During winter 2005-2006 the lake underwent a complete overturn, resulting in an influx of nutrient rich hypolimnetic water into the upper productive layers and oxygenated epilimnetic water into the deepest water layers. The effect of full overturn on the phytoplankton community is described and compared with those of meromictic years. The interplay between natural and anthropological processes on water quality and water usages is also discussed.
\end{abstract}

Key words: Volcanic lake, meromixis, eutrophication, chemical precipitation, water level, water quality

\section{INTRODUCTION}

Lake Albano, for its location near Rome (Fig. 1), was considered for early limnological studies from the end of the 19th century, when Marinelli $(1894-95,1902)$ and De Agostini $(1898,1917)$ studied the bathymetry and showed temperature profiles of the lake. In the first half of the $20^{\text {th }}$ Century several authors considered the biology of the lake, often using a comparative approach with other volcanic lakes in Latium (for a literature review see: Stella \& Socciarelli (1950) and Margaritora (1992)). Most of these papers focussed on zooplankton and to some extent on macro benthos, (e.g., Stella \& Socciarelli 1950; Stella \& Argenti 1953; Margaritora et al. 1988; Mastrantuono 1990) with scarce information on phytoplankton (Cannicci 1953; Margaritora et al. 1988, Bazzanti \& Seminara 1995).

Catastrophic hydrologic events (such as lahars) at Lake Albano have been recorded by its sediments. The lake stratigraphy and Roman historians (from Plutarcus to Titus Livius, see Funiciello et al. 2002) have shown rapid and substantial water level variations and lake withdrawal possibly caused by rapid variations in $\mathrm{CO}_{2}$ flow and up-welling of hydrothermal fluids (Funiciello et al. 2002, 2003; Bersani \& Castellani 2005). Since the 1990s, the whole volcanic complex has been more intensely studied because of the potential risk posed to the local population from hazardous levels of $\mathrm{CO}_{2}$ that continue to arise from residual magmatic activity
(Funiciello et al. 2002, 2003; Beaubien et al. 2003; Tuccimei et al. 2006). Due to the instability of the area resulting from earth tremors and residual thermal activity the possibility of lake-rollover and $\mathrm{CO}_{2}$ limnic eruption is thought to pose the highest threat of the volcano today (Funiciello et al. 2003). Underwater gas springs have been documented from direct observation through bathyscaphe methodologies (Capelli et al. 1998) and gas saturation of the bottom waters have been shown from isotopic studies (Carapezza et al. 2008). The processes involved in a limnic eruption could follow those of the tragic events that occurred in Lakes Nyos and Monoun in 1996 (Sigurdsson et al. 1987; Rice 2000), although $\mathrm{CO}_{2}$ concentrations at Albano Lake are at much lower levels.

Volcanic lakes generally have small catchment areas and so the physical and chemical characteristics of their water tend to reflect water-rock interactions that occur in and beneath the lake as well as variations in the flux of heat and volatile compounds derived from subsurface hydrothermal/magmatic systems (Varekamp et al. 2000). The water chemistry of Lake Albano is assumed to mainly derive from these subterranean interactions; the elevated $\mathrm{CO}_{2}$ concentrations of the monimolimnion have been shown to be volcanic and not of biological origin (Martini et al. 1994; Cioni et al. 2003). The large relative depth to surface area of Lake Albano results in a high hydrostatic pressure at the base of the lake which holds the $\mathrm{CO}_{2}$ saturated water at depth. But high $\mathrm{CO}_{2}$ 


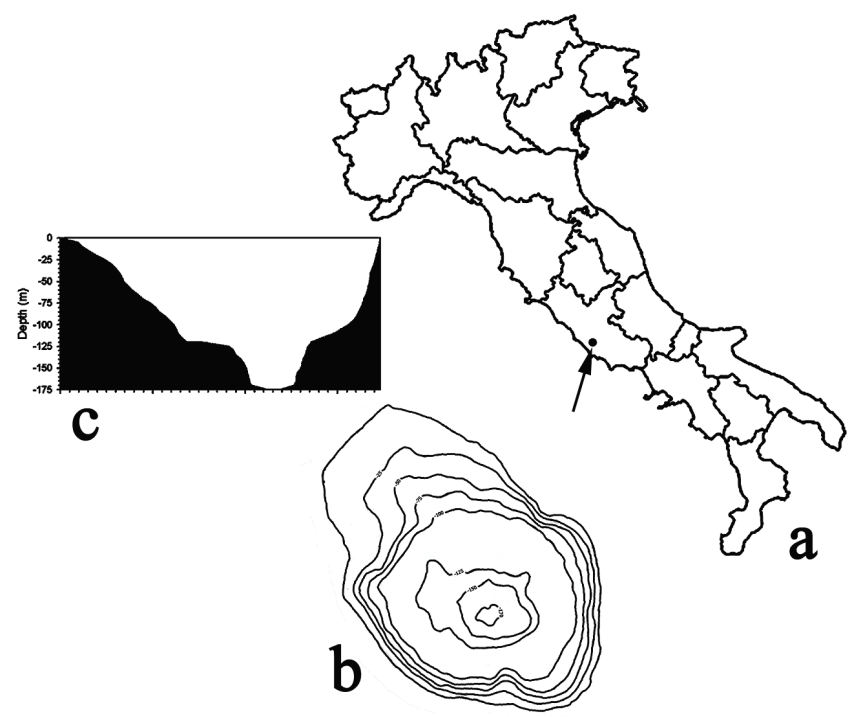

Fig 1. Geographical position of Lake Albano within the Italian peninsular (a), bathymetric map (b) and a cross sectional profile of the lake from NW to SE of the lake (c).

concentrations can reduce this stability and small perturbations such as landslides, heavy/cold rainwater, internal waves, groundwater surges into the lake could move the water up sufficiently to reach saturation $\left(\mathrm{pCO}_{2}\right.$ $=\mathrm{p}$ total) leading to a possible limnic eruption (ex-solution) of $\mathrm{CO}_{2}$ at the surface (Zhang 1996). As mentioned above similar events have occurred on a catastrophic scale at lakes Nyos and Monoun of Cameroon. The large $\mathrm{CO}_{2}$ storage capacity of Lake Albano and the underlying possibility of gas ex-solution may hold some considerable risk amongst all the residual thermal anomalies of the Colli Albani Volcano (Funiciello et al. 2003).

Comprehensive paleolimnological studies have been carried out at the lake within the EU project PALICLAS (Guilizzoni \& Oldfield 1996; Chondrogianni et al. 1996). From analysis run on a $15 \mathrm{~m}$ sediment core extracted at a depth of $70 \mathrm{~m}$; the presence of annual varves down to the bottom of the core (1700 AD) indicated the lack of bioturbation and likely long-term meromixis, meaning that deeper waters (monimolimnion) never or rarely mix with the upper water layers (Lami et al. 1994; Guilizzoni et al. 2002). These studies showed strong decreases in the concentrations of biological proxies, such as, pollen, algal pigments and biological remains and linked them to nine major deforestation events of the mid-Holocene climatic transition. Most of the indicated environmental changes were synchronized with those in nearby Lake Nemi and with those in the Adriatic Sea, indicating the importance of regional rather than local effects (Guilizzoni et al. 2002). The evaluation of the trophic state of the lake from cored sediments was difficult due to the past meromictic characteristics of the lake. However, based on algal pigments and zooplankton remains, the onset of eutrophic conditions approximately, dates back to 1870 . This is likely due to an increase in the human population within the watershed (Lami et al. 1992, 1994). Eutro- phication caused by anthropogenic activity in the 1960s and 70s was shown by an increment in the cyanobacterial pigments contained in the sediments (Margaritora 1992; Lami et al. 1994). Phosphorus, chlorophyll and water transparency measurements performed by Pagnotta et al. (1986) on Latium lakes resulted in a meso-eutrophic classification of Lake Albano which has been echoed in many other studies carried out since (Provini et al. 1992).

Furthermore, during the last 10 to 15 years over-extraction of water and groundwater from Lake Albano watershed has led to a dramatic lowering of the water level (Capelli et al. 1998). A recent study has estimated a level lowering of $2.67 \mathrm{~m}$ from 1984 to 2003 corresponding to a water loss of around $16 \mathrm{Mm}^{3}$ (Medici 2005). This reduction in lake volume may have major consequences regarding the water quality of Lake Albano. Combined with a long water renewal time (47 years) and increase urban inputs, chiefly from sewage effluents and to a lesser extent from surface run-off to the lake, the problems associated with increasing lake trophy have been exacerbated. A well know consequence of eutrophication is an increase of cyanobacterial growth and potential bloom formation (Paul 2007). Many bloom forming cyanobacteria are known to produce toxins, which when produced in sufficient quantities can cause death of animals and pose risk to human health (Briand et al. 2003). Toxin analyses of Lake Albano have revealed six different microcystin variants at concentrations up to $14 \mu \mathrm{g} \mathrm{L}^{-1}$ (Bogialli et al. 2006; Messineo et al. 2006). These levels are well above those recommended by the World Health Organisation (provisional value $1 \mu \mathrm{g} \mathrm{L}^{-1}$ for free and cell-bound microcystin-LR; WHO 2003). In the study of Messineo et al. (2006) it was also shown that the groundwater system was contaminated with trace levels of cyanotoxins which poses a potentially significant threat to drinking 
water supplies. Depending on the climate, blooms can extend for long periods, while most blooms extend from late autumn to mid-spring (Pomati et al. 2000; Gentian et al. 2005; Paul 2007).

Despite the economic, historical and touristic importance of Lake Albano (Castel Gandolfo the summer residence of the Pope and the home of the Vatican Observatory are within the watershed) to date there has been no long-term limnological study. The combination of residual volcanic activity, lake level lowering and the presence of toxic cyanobacterial blooms indicates with confidence that the lake water quality has significantly deteriorated and that its usages are becoming limited. Thus there is a pressing need to assess the extent of this loss and to identify remedial actions. This paper aims to combine a detailed four-year water quality (chemistry and biology) study, with a review of past data and speciation modelling to identify and assess the changes that occur within the lake seasonally and throughout the water column. The paper also aims to identify the causal agents involved in the deterioration of the water quality and to discuss the role of physical (winter and springwater overturn) and chemical processes (nitrogen $[\mathrm{N}]$ and phosphorus $[\mathrm{P}]$ dynamics, the precipitation of calcite, and the co-precipitation of $\mathrm{P}$ and other compounds).

\section{STUDY AREA, SAMPLING STRATEGY AND METHODS}

Figure 1 and table 1 show location and morphometric characteristics of Lake Albano. The lake is located on the west slope of the Colli Albani volcano; $293 \mathrm{~m}$ a.s.1., $24 \mathrm{~km}$ southeast of Rome city centre, Italy. The lake is of elliptical shape, elongated in NW-SE direction, and fills two coalescent craters representing the last known eruptive products of the volcano. The volcano still shows frequent seismic activity, local uplift, hydrothermal circulation and gas emissions (mostly $\mathrm{CO}_{2}, \mathrm{H}_{2} \mathrm{~S}, \mathrm{HF}$ ) indicating that there is still energy in the volcanic system and it represents a geologic hazard (Chiarabba et al. 1994, 1997; Calcara et al. 1995; Giordano et al. 2000; Pizzino et al. 2000; Funiciello et al. 2002). During a hydrogeological study of the area two aquifers systems were identified as feeding the lake: one regional and one perched (Capelli et al. 2000). According to the authors, the upper surface of the regional aquifer lie $200 \mathrm{~m}$ a.s.l. and as the lake extends from 290-170 m a.s.l. it intercepts water from both aquifers. The lake has a surface area of $5.2 \mathrm{~km}^{2}$, perimeter of $10 \mathrm{~km}$ and a maximum depth of $\sim 170 \mathrm{~m}$. The lake is predominantly fed by groundwater sources and in the past was drained by a unique artificial outlet (a $1.5 \mathrm{~km}$ tunnel traversing the crater wall, constructed around 398-397 BC). Since the early 1990s, because of the increasingly lower lake level due to high urbanisation and over exploitation of groundwater resources, the tunnel no longer drains the lake water and the down- stream outlet has been walled up for hygienic reasons. The present-day water level is nearly four metres lower than in 1960. The climate of the area is considered to be Mediterranean; the area has also been classified as maritime with respect to rainfall (Capelli et al. 1998).

Tab. 1. Main morphometric and hydrological characteristics of Lake Albano. Watershed area not including lake surface.

\begin{tabular}{lcc}
\hline Characteristic & Units & Value \\
\hline Lake level & $\mathrm{m} \mathrm{a.s.l.}$ & 293 \\
Watershed area (Wa) & $\mathrm{km}^{2}$ & 9.6 \\
Maximum watershed altitude & $\mathrm{m} \mathrm{a.s.l.}$ & 556 \\
Lake area (La) & $\mathrm{km}^{2}$ & 6.02 \\
Wa/La ratio & & 1.6 \\
Lake perimeter & $\mathrm{km}$ & 10 \\
Maximum depth & $\mathrm{m}$ & 170 \\
Mean depth & $\mathrm{m}$ & 77 \\
Volume & $10^{6} \mathrm{~m}^{3}$ & 464 \\
Water renewal time & $\mathrm{y}$ & 47.6 \\
\hline
\end{tabular}

Typical chemical and biological parameters were monitored at the point of maximum depth, with 11 sampling depths from surface to bottom $(160 \mathrm{~m})$. Five to six samplings per year were carried out from February 2004 to February 2008. For ease of data handling average values (volume weighted) for the epilimnion $(0-15 \mathrm{~m})$ and hypolimnion (15-160 m) have been reported.

Water chemistry of the lakes Bolsena, Mergozzo, Maggiore, Lugano, Como, Iseo and Garda, used for the comparison of the inorganic carbon equilibrium with Lake Albano, was obtained by analyses performed in the same laboratory with the same analytical methods. The relationship between $\mathrm{pH}$ and bicarbonate at different atmospheric partial pressure of carbon dioxide used to discuss the inorganic carbon equilibrium of the waters is described by Stumm and Morgan (1981). In particular, the stoichiometric approach of the equilibrium of solutes in aqueous carbonate solution has been used, having the effect of simplifying the Lake Albano waters to a solution of calcium carbonate. The equilibrium constants of inorganic carbon and calcite solubility used, reported by the same text, are corrected for the lake temperature and water ionic strength (the extended Debye-Huckel approach, as the ionic strength of Lake Albano and of the other lakes considered have ionic strengths below $10^{-1} \mathrm{M}$ ). The presented values of atmospheric carbon dioxide were assumed to be 370 ppmv (Karl \& Trenberth 2003).

Depth profiles of temperature, conductivity, oxygen and $\mathrm{pH}$ were made at $5 \mathrm{~m}$ intervals from 0 to $30 \mathrm{~m}$ and $10 \mathrm{~m}$ intervals between 30 and $160 \mathrm{~m}$ using a multiprobe (Hydrolab, minisonde 4a). Redox potential profiles were included from October 2005 (Hydrolab, minisonde MS5). Secchi depth measurements were made by the same operative at the same time during each sampling trip from the shaded side of the boat. Water samples were collected into 1-L high density polyethylene 
bottles pre-washed by soaking for $24+\mathrm{h}$ in Detergent- 8 (Alconox, USA) and then rinsed four times with deionised water. All samples were transported on ice to the laboratory.

Measurements of alkalinity, filtration of lake water for chlorophyll- $a$ (Chl- $a$ ) determination, filtration of water samples for dissolved nutrient analyses and fixation of samples for counts were made upon return to the Biology of Algae Laboratory, University of Tor Vergata, Rome. Chl- $a$ analyses involved the filtration of a known volume of lake water through a $45 \mu \mathrm{m}$ Whatman GFC filter, using vacuum pump at $14 \mathrm{KPa}$ (Gelman Little Giant, Gelman Sciences). The filters were left overnight in $5 \mathrm{~mL}$ of acetone $(90 \%)$ at $4{ }^{\circ} \mathrm{C}$. The Chl- $a$ content of the extract was estimated according to a spectrophotometric method described by Marker (1972). Analyses of inorganic fractions were performed within $24 \mathrm{~h}$ of sampling. Lake water was filtered through 0.45 $\mu \mathrm{m}$ cellulose-acetate membranes (pre-washed with $10 \%$ $\mathrm{HCl}$ and rinsed with deionised water). From frozen, filtered total- and total-P and total- $\mathrm{N}$ were measured within the same week of the sampling trip. $\mathrm{NH}_{4}-\mathrm{N}$ was determined spectrophotometrically by the absorbance of indophenol blue (Solórzano 1969). $\mathrm{NO}_{2} \cdot \mathrm{NO}_{3}-\mathrm{N}$ was determined using a second derivative UV/visible spectroscopical method (Ferree \& Shannon 2001). Soluble Reactive Phosphorous (SRP) and analysis of phosphates were measured by molybdate colorimetry (Murphy \& Riley 1962). Measures of total $\mathrm{N}$ and $\mathrm{P}$ were made on filtered and unfiltered samples following persulphate digestion (Langer \& Hendrix 1982). Organic N and P were calculated as the difference between total and inorganic fractions.

Major ion and trace element analyses were carried out on spring and late autumn samples at the CNR Institute of Ecosystem Study, where nutrient concentrations were also measured, for a comparison between the two laboratories. Chemical variables considered were, $\mathrm{pH}$ and conductivity (APAT, IRSA-CNR 2003 and A.P.H.A. 1992), alkalinity (A.P.H.A. 1992, Gran 1952) and nitrate, sulphate, chloride by ion chromatography (APAT, IRSA-CNR 2003). Ca, Mg, Na, K by I.C.P. Optical Emission Spectroscopy (APAT, IRSA-CNR. 2003), reactive and total P (Valderrama 1977, 1981), nitrite and total N (A.P.H.A. 1992), reactive silica (Golterman 1978). Limited to spring and autumn samples of 2006 and 2007, the trace elements (Al, As, B, $\mathrm{Ba}, \mathrm{Fe}, \mathrm{Li}, \mathrm{Mn}, \mathrm{Se}, \mathrm{Sr}, \mathrm{V}, \mathrm{Zn}$ ) were also measured by ICP OES (Simultaneous ICP-OES Vista MPX axial configuration, Varian with concentric and ultrasonic nebuliser, CETAC.) following U.S. E.P.A. (1994, 1996), ISO 11885 (1996), A.P.H.A. (2005) and APAT IRSA-CNR (2003). The concentrations of $\mathrm{Cd}, \mathrm{Co}, \mathrm{Cr}$, $\mathrm{Cu}, \mathrm{Ni}, \mathrm{Pb}, \mathrm{Pt}, \mathrm{Ti}$, were below their respective detection limits and were therefore not considered.

Visual MINTEQ was used to calculate the equilibrium composition of dilute aqueous and precipitated compounds throughout the water column of Lake Albano. VMINTEQ is the windows version of the MINTEQA2 model (Allison et al. 1991; Allison \& Brown 1995) which is a geochemical equilibrium speciation model for dilute aqueous systems. The model has an extensive thermodynamic database that is adequate for solving a broad range of problems without need for additional user-supplied equilibrium constants. The data also included trace elements. The model calculated the concentrations of possible chemical species, their mass distribution but more importantly the saturation index $(\mathrm{SI}=\log \mathrm{IAP}-\log \mathrm{Ks})$ for a number of minerals. The saturation index of minerals was then used to identify possible mineral crystallisation or dissolution phases. When SI values are less than zero, the water is considered under-saturated with respect to that mineral. A positive SI value indicates super-saturation and the potential for the mineral to precipitate. The zero SI value shows saturation or equilibrium state. In practice, SI values in between -0.5 and +0.5 will indicate a great potential for the formation of solid forms. The data used in the model was from the summer of 2007 at four different depths $(0,10,140$ and $160 \mathrm{~m})$.

Weighted means were based on volumes of strata bonded by any two depths calculated by a polynomial fit to the cumulative volume curve obtained from a bathymetric map of the lake. Means for each determinand were based on three repeats, coefficients of variation were used to assess the large variability (seasonal and spatial) of Chl- $a$. Correlation coefficients ( $r$ and $P$ values) to determine relationships among lake water and biological determinands, were calculated using SPSS v.10 for Windows (Chicago, Illinois, USA).

\section{RESULTS}

\subsection{Temperature and oxygen concentrations}

Temperatures below $30 \mathrm{~m}$ down to the bottom of the lake are very stable and range between 8.5 to $9.0{ }^{\circ} \mathrm{C}$ (Fig. 2). During the winter months the difference of temperature between epilimnic waters $(0-10 \mathrm{~m})$ and the deepest layers $(50-160 \mathrm{~m})$ fall between 0.2 and $0.01{ }^{\circ} \mathrm{C}$ in January and March. The temperature of the euphotic zone was highly variable; the changes across time and depth are given in figure 2 ranging from 27.4 $(11 / 08 / 08)$ to $8.1{ }^{\circ} \mathrm{C}(31 / 01 / 05)$. Well defined thermal stratification occurred from April-May to OctoberNovember. The thermocline is variable ranging from the surface down to $20 \mathrm{~m}$, with gradients of around $1.5-2.0$ ${ }^{\circ} \mathrm{C} \mathrm{m}^{-1}$. White boxes occurring between $06 / 08 / 06$ to $14 / 05 / 07$ indicate periods where no data was available as sampling was not possible.

Oxygen profiles are shown in figure 2 for the first 50 $\mathrm{m}$. During winter the superficial water $(0-20 \mathrm{~m})$ remains saturated with rapid depletion with increasing depth to trace levels normally occurring between 30 and $50 \mathrm{~m}$. Whilst in spring and summer the $\mathrm{O}_{2}$ profile, indicated a full overturn with $\mathrm{O}_{2}$ diffusion to deeper water 


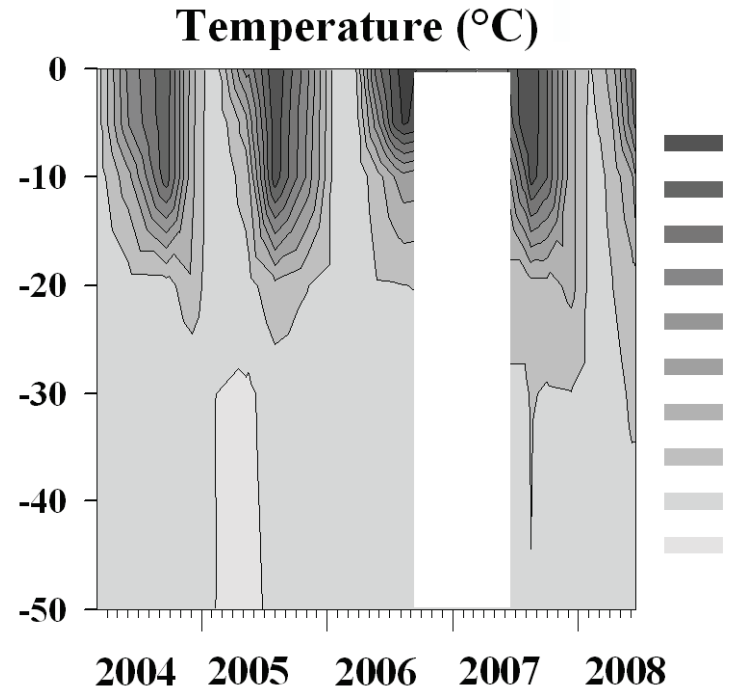

\section{Dissolved Oxygen (mg L $\left.{ }^{-1}\right)$}

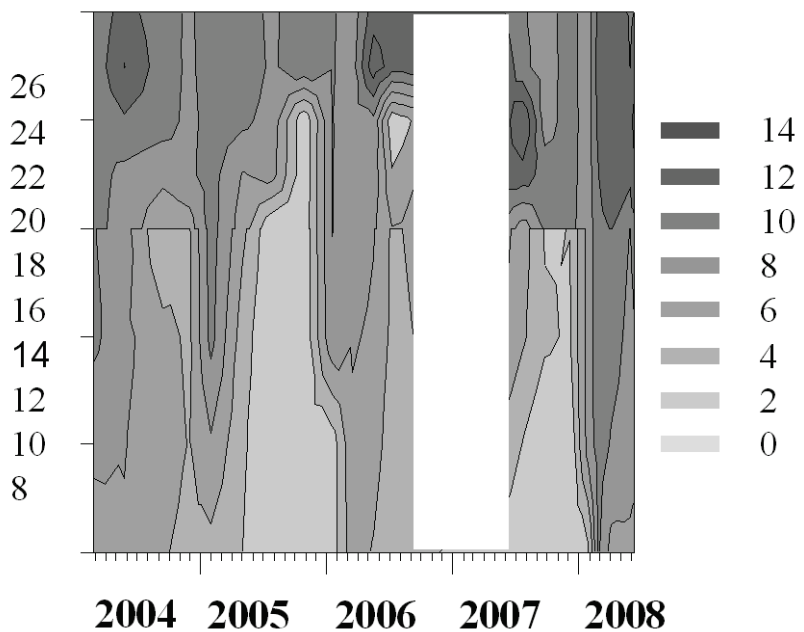

Fig. 2. Seasonal changes in the depth profiles $(50 \mathrm{~m})$ of temperature $\left({ }^{\circ} \mathrm{C}\right)$ and dissolved oxygen concentrations $\left(\mathrm{mg} \mathrm{L} \mathrm{L}^{-1}\right)$ in $\mathrm{Lake}$ Albano March 2004 to June 2008. White spaces indicate missing data between 06/08/06 and 14/05/07.

layers down to $60 \mathrm{~m}$ and concentration about $5 \mathrm{mg} \mathrm{L}^{-1}$ (see Fig. 4). Similar $\mathrm{O}_{2}$ profiles have been observed by Carapezza et al. (2008) and Cioni et al. (2003).

\section{2. $p H$, major ions and conductivity}

Values of $\mathrm{pH}$ show seasonal fluctuations in the epilimnion typical of productive, hard water lakes, with maximum values of $8.7-8.9$ in the upper $10 \mathrm{~m}$ from late spring to autumn, and minima of 7.6 - 7.9 during winter and early spring. On the other hand, values are unusually low in the hypolimnion $(\mathrm{pH} 7.1$ - 7.5). Accounting for this occurrence, with prevailing conditions of oxygen depletion, strongly implies a possibility of high carbon dioxide concentrations in the hypolimnion. This feature has already been implied by Cioni et al. (2003) and Mosello et al. (2004) and has been associated with volcanic sub-surface $\mathrm{CO}_{2}$ springs (Funiciello et al. 2003; Tuccimei et al. 2006). The effect of the $\mathrm{CO}_{2}$ concentration in the hypolimnion of Lake Albano compared with that of other Latium and Northern Italian lakes is evident in figure 3 . While most of the hypolimnetic values of all the lakes are in the equilibrium range with a partial pressure of $\mathrm{CO}_{2}$ between $10^{-3}$ and $10^{-2}$ atm, Lake Albano values are in the range between $10^{-2}-10^{-1}$ atm. No relevant differences were found for surface values.

The chemical composition of Lake Albano waters (Tab. 2, May 2007) shows a prevalence of calcium (30\% of the total cation concentration) with slightly lower magnesium, sodium and potassium contents, at $24.4,23.6$ and $21.6 \%$ respectively. Alkalinity is predominant among the anions, constituting about $87 \%$ of the total; the other anions are chloride $(10 \%)$ and sulphate $(2.6 \%)$, while nitrate is negligible. The total ion concentration is $11.2 \mathrm{meq} \mathrm{L}^{-1}$, with a corresponding conductivity of $484 \mu \mathrm{S} \mathrm{cm}^{-1}$ at $20{ }^{\circ} \mathrm{C}$ which is slightly higher when compared with other volcanic Italian lakes $\left(400-450 \mu \mathrm{S} \mathrm{cm}^{-1}\right)$ and much higher than Alpine lakes $\left(150-250 \mu \mathrm{S} \mathrm{cm}^{-1}\right)$.

The depth profiles of major ions shows a decrease of calcium and alkalinity in the epilimnion during summer and autumn, with no variations for the other ions which remained within the limits of the analytical errors (Tab. 2, July 2007 sampling). The gradient concentration between the epilimnion $(0-30 \mathrm{~m})$ and hypolimnion $(30$ $\mathrm{m}-160 \mathrm{~m})$ is determined from the precipitation of calcium carbonate from the trophogenic layer, and from a partial re-dissolution of the sinking calcite in the hypolimnion enhanced by the high oversaturation of $\mathrm{CO}_{2}$. No variations in the magnesium concentrations were observed, which indicated that there was no precipitation of dolomite or other magnesium minerals in the epilimnion. Furthermore, an extensive comparison including data from all sampling depths confirmed the strong direct relation between alkalinity and calcium $(r$ $=0.95, P<0.01)$ as well as of both variables and conductivity $(r=0.98,0.94, P<0.01)$.

\subsection{Nitrogen, phosphorus and silica}

Mean annual concentrations of the three measured $\mathrm{N}$ forms (ammonium, $\mathrm{NH}_{4}-\mathrm{N}$; nitrate, $\mathrm{NO}_{3}-\mathrm{N}$; total nitrogen TN) and calculated values of inorganic and organic $\mathrm{N}$ (in- $\mathrm{N}$, org-N) are shown in table 3 . When measured, nitrite- $\mathrm{N}$ concentrations were always lower than $10 \mu \mathrm{g}$ $\mathrm{N} \mathrm{L}^{-1}$. Higher concentrations of org-N were found in the productive upper layers (about $70 \%$ of $\mathrm{TN}$ ), followed by $\mathrm{NO}_{3}-\mathrm{N}(20 \%)$. In the hypolimnion, $\mathrm{NH}_{4}$ is the most prevalent $\mathrm{N}$ species $(40 \%)$, followed by org- $\mathrm{N}$ and $\mathrm{NO}_{3}$ $\mathrm{N}$ (34 and $26 \%$ respectively). The vertical profiles of $\mathrm{N}$ forms during summer stratification (Fig. 4), highlights $\mathrm{NO}_{3}-\mathrm{N}$ peaks between 30 and $70 \mathrm{~m}$, large increases $\mathrm{NH}_{4}-\mathrm{N}$ concentration below $70 \mathrm{~m}$ and org-N peaks in the upper and lower parts of the depth profile. 


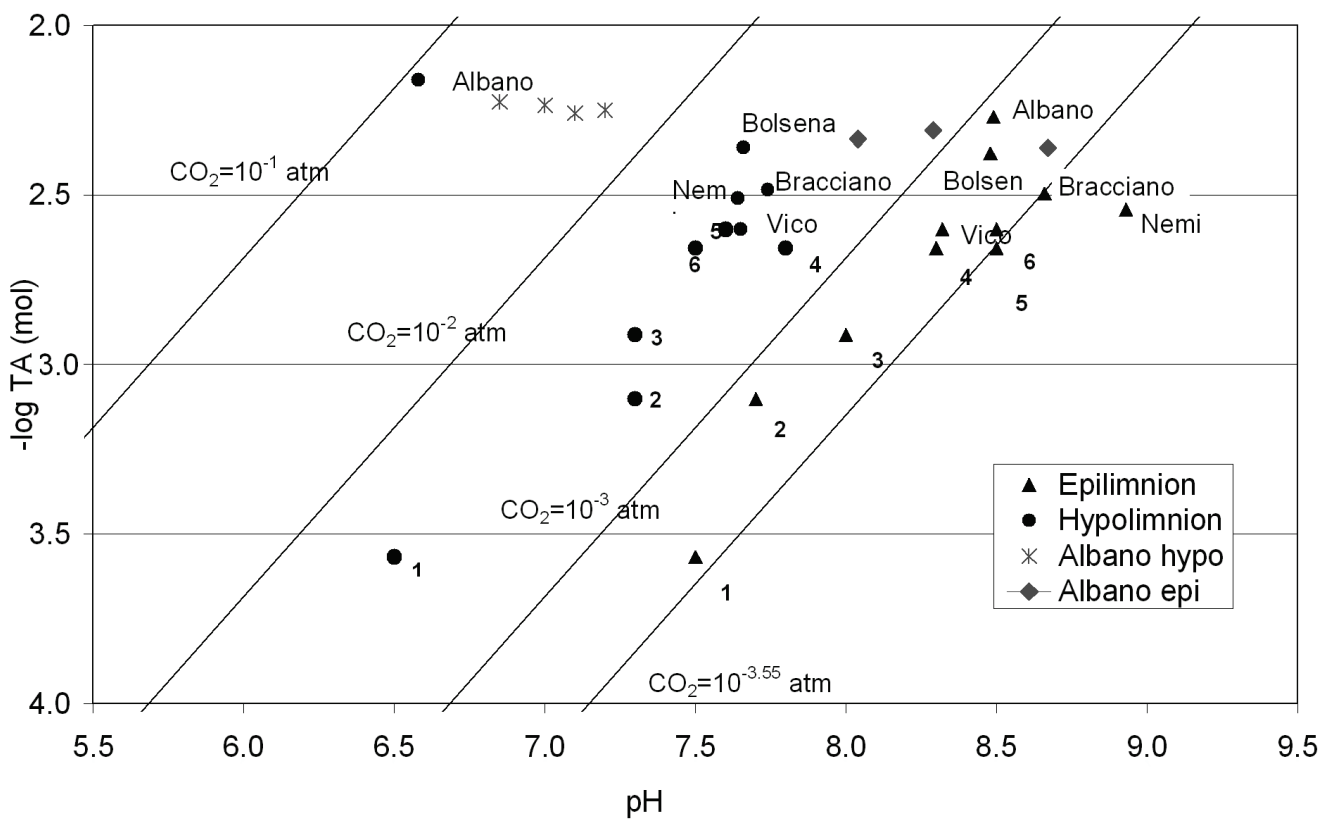

Fig. 3. Relationship between $\mathrm{pH}$ and total alkalinity in water of the surface and deep waters of the five Latium lakes compared with those of deep southern alpine lakes Mergozzo (1), Maggiore (2), Como (3), Garda (4), Lugano (5) and Iseo (6) at the summer stratification. The lines indicate the equilibrium values for the dissolution of calcite at different values of partial pressure of $\mathrm{CO}_{2}$.

Tab. 2. Major cation, anions, $\mathrm{pH}$, ion balance $\left(\mu \mathrm{eq} \mathrm{L}^{-1}\right)$ and conductivity $\left(\mu \mathrm{S} \mathrm{cm}^{-1}\right.$ at 20 ${ }^{\circ} \mathrm{C}$ ) of Lake Albano measured in 14/05/07 and 23/07/07. Values are means (weighted for volume) calculated for the epilimnion (0-10 m), the hypolimnion (20-160 m) and the whole depth profile $(0-160 \mathrm{~m})$

\begin{tabular}{|c|c|c|c|c|c|c|}
\hline & \multicolumn{3}{|c|}{$14 / 05 / 07$} & \multicolumn{3}{|c|}{$23 / 07 / 07$} \\
\hline & $0-10 \mathrm{~m}$ & $20-160 \mathrm{~m}$ & $0-160 \mathrm{~m}$ & $0-10 \mathrm{~m}$ & $20-160 \mathrm{~m}$ & $0-160 \mathrm{~m}$ \\
\hline $\mathrm{Ca}$ & 1634 & 1801 & 1773 & 1226 & 1531 & 1479 \\
\hline $\mathrm{Mg}$ & 1323 & 1345 & 1341 & 1434 & 1415 & 1418 \\
\hline $\mathrm{Na}$ & 1284 & 1287 & 1287 & 1350 & 1334 & 1337 \\
\hline $\mathrm{K}$ & 1176 & 1196 & 1193 & 1281 & 1244 & 1250 \\
\hline $\mathrm{NH}_{4}$ & 0 & 16 & 14 & 0 & 19 & 16 \\
\hline $\mathrm{Sr}$ & 16 & 18 & 17 & 15 & 17 & 17 \\
\hline Total cations & 5434 & 5664 & 5625 & 5107 & 5359 & 5316 \\
\hline $\mathrm{HCO}_{3}$ & 4730 & 4938 & 4903 & 4423 & 4916 & 4832 \\
\hline $\mathrm{Cl}$ & 542 & 543 & 543 & 563 & 543 & 547 \\
\hline $\mathrm{NO}_{3}$ & 1 & 10 & 9 & 1 & 6 & 5 \\
\hline $\mathrm{SO}_{4}$ & 138 & 131 & 132 & 135 & 120 & 123 \\
\hline Total anions & 5411 & 5622 & 5586 & 5122 & 5586 & $\mathbf{5 5 0 7}$ \\
\hline Total ions & 10845 & 11286 & 11211 & 10229 & 10945 & 10822 \\
\hline Conductivity & 463 & 488 & 484 & 446 & 490 & 482 \\
\hline $\mathrm{pH}$ & 8.78 & 7.57 & 7.78 & 8.57 & 7.53 & 7.71 \\
\hline
\end{tabular}

Tab. 3. Mean lake concentrations of nitrogen, phosphorus and silica forms.

\begin{tabular}{lcccc}
\hline & & $0-10 \mathrm{~m}$ & $20-160 \mathrm{~m}$ & $0-160 \mathrm{~m}$ \\
\hline Ammonium & $\left(\mu \mathrm{g} \mathrm{N} \mathrm{L}^{-1}\right)$ & 33 & 287 & 243 \\
Nitrate & $\left(\mu \mathrm{g} \mathrm{N} \mathrm{L}^{-1}\right)$ & 86 & 189 & 171 \\
Inorganic nitrogen & $\left(\mu \mathrm{g} \mathrm{N} \mathrm{L}^{-1}\right)$ & 119 & 476 & 415 \\
Organic nitrogen & $\left(\mu \mathrm{g} \mathrm{N} \mathrm{L}^{-1}\right)$ & 307 & 240 & 251 \\
Total nitrogen & $\left(\mu \mathrm{g} \mathrm{N} \mathrm{L}^{-1}\right)$ & 427 & 716 & 666 \\
Soluble reactive P & $\left(\mu \mathrm{g} \mathrm{P} \mathrm{L}^{-1}\right)$ & 11 & 94 & 80 \\
Filtrable organic P & $\left(\mu \mathrm{g} \mathrm{P} \mathrm{L}^{-1}\right)$ & 27 & 108 & 94 \\
Total P & $\left(\mu \mathrm{g} \mathrm{P} \mathrm{L}^{-1}\right)$ & 41 & 136 & 120 \\
Reactive silica & $\left(\mu \mathrm{g} \mathrm{Si} \mathrm{L}^{-1}\right)$ & 0.06 & 0.66 & 0.56 \\
\hline
\end{tabular}




\section{Nitrogen $\left(\mu \mathrm{g} \mathbf{L}^{-1}\right)$}

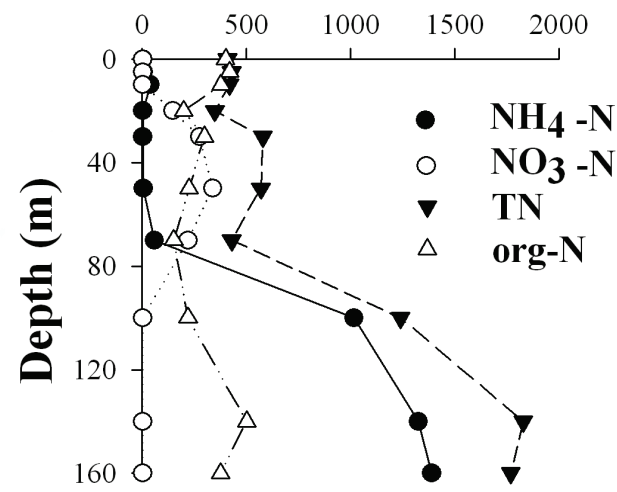

Fig. 4. Vertical profile of nitrogen forms on July 2005.

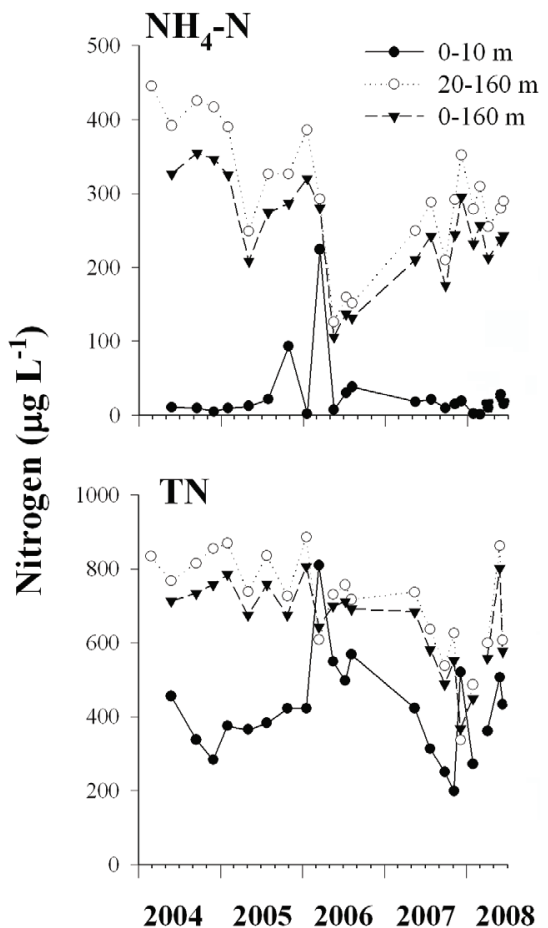

The different $\mathrm{P}$ forms concentrations (Tab. 3) indicate mean values slightly higher than $10 \mu \mathrm{g} \mathrm{P} \mathrm{L}^{-1}$ in the $0-10 \mathrm{~m}$ layer for Soluble RP and Soluble TP, and values between 27 and $41 \mu \mathrm{g} \mathrm{P} \mathrm{L}^{-1}$ for unfiltered RP and TP. Concentrations of all the $\mathrm{P}$ forms increased in the deeper water layers, reaching mean values close to or higher than $100 \mu \mathrm{g} \mathrm{P} \mathrm{L}^{-1}$ in the water layer $20-160 \mathrm{~m}$, with the highest values of $300-400 \mu \mathrm{g} \mathrm{TP} \mathrm{L^{-1 }}$ in the water layer $140-160 \mathrm{~m}$. The variations along the four years of observations show a strong peak in the upper water layer coinciding with the winter 2005-06 water mixing (Fig. 6), while the increase due to the mixing of the winter 2006-07 was not detected because of the lack of spring sampling.

Reactive silica (Tab. 3) shows low values in the productive layers, as an effect of the diatom uptake,

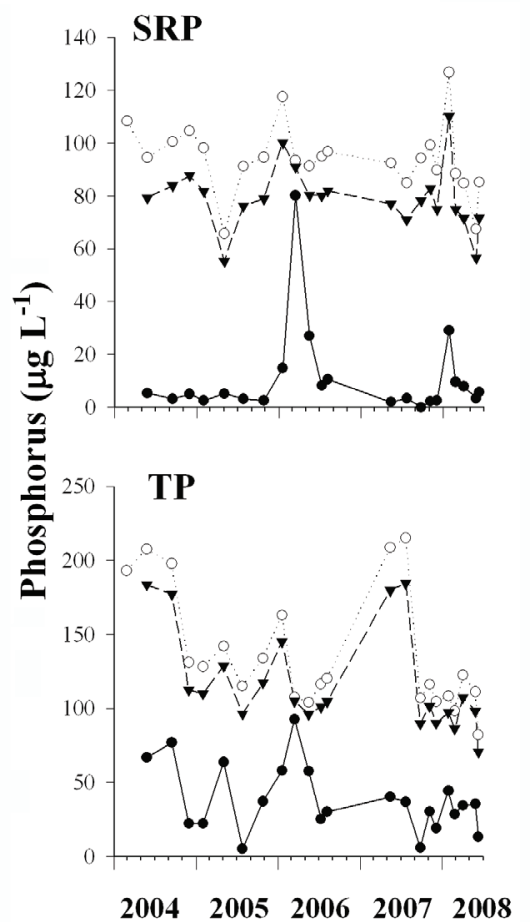

Fig. 5. Plots of mean (volume weighted) $\mathrm{NH}_{4}-\mathrm{N}, \mathrm{TN}, \mathrm{SRP}$ and $\mathrm{TP}$ in the epilimnion (0-10 m), hypolimnion (20-160 m) and the whole lake $(0-160 \mathrm{~m})$.

The variation of the $\mathrm{NH}_{4}-\mathrm{N}$ and $\mathrm{NO}_{3}-\mathrm{N}$ concentration as function of time during the four year study (Fig. 5) shows a decrease of $\mathrm{NH}_{4}$ concentrations in 2005 , followed by a more marked decrease in 2006. These variations agree with a $\mathrm{NO}_{3}$ increment during summer autumn 2006 when it reached the highest concentration of $410 \mu \mathrm{g} \mathrm{N} \mathrm{L}^{-1}$. These variations are related to the two water mixing episodes and to the consequent oxygen input to the deeper anoxic layers, producing ammonium oxidation and $\mathrm{NO}_{3}-\mathrm{N}$ production. As a result, $\mathrm{NO}_{3}-\mathrm{N}$ concentrations in the productive layers remained higher in years 2006 and 2007, compared to the values found in 2004 and 2005. while concentrations reach values between 1.5-2.0 $\mathrm{mg} \mathrm{Si} \mathrm{L^{-1 }}$ in the water below the depth of $100 \mathrm{~m}$. The effect of the winter 2005-06 is evident, with a redistribution of concentrations along the water column with the highest value of $0.3 \mathrm{mg} \mathrm{Si} \mathrm{L}{ }^{-1}$ in the $0-10 \mathrm{~m}$ layer (Fig. 6).

The effect of the winter over turn on the nutrient and dissolved oxygen profiles is shown in figure 6. During mixing, there was a large decrease in deepwater and an increase in the surface nutrient concentrations. Oxygen concentrations were much higher in the deeper water, with oxygenated water present throughout the whole depth profile. 


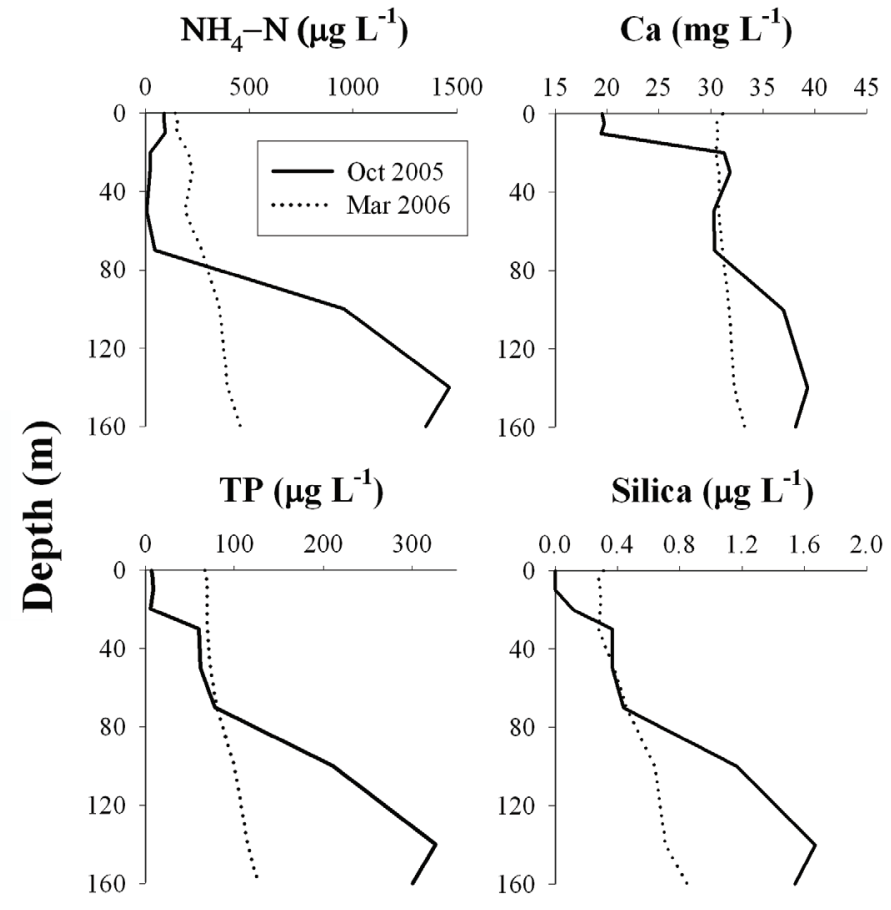

Fig. 6. Effect of Winter 2005-06 overturn on some chemical variables in Lake Albano.

\subsection{Trace elements}

Twenty trace elements were measured during the summers of 2005, 2007 and winter 2008. The results for the summer campaign of 2005 are presented in table 4 . The concentrations found for $\mathrm{Pb}, \mathrm{Hg}$ and $\mathrm{Ni}$ were under Maximum Allowable Concentrations (MAC) quality criteria given by the European Environmental Agency in its Water Framework Directive (EEA 2008). Under their respective DL were $\mathrm{As}, \mathrm{Cd}, \mathrm{Cr}$ and $\mathrm{Cu}$, but, $\mathrm{Fe}$ and $\mathrm{Mn}$ were always measurable and increased dramatically with depth. Ba doubled in concentration from surface to bottom water layers. According to the VMINTEQ, the chemical species expected to be formed (Fig. 7 and Tab. 5) would include Fe and $\mathrm{Mn}$ compounds associated to $\mathrm{Al}$ and $\mathrm{CO}_{2}$ in surface waters and would show some potential for precipitation at bottom layers. These can be seen in figure 7 where SI values were lower at the surface and increased with depth.

At present and unfortunately, water quality standards only exist for $\mathrm{Cd}, \mathrm{Pb}, \mathrm{Hg}$ and $\mathrm{Ni}$ under the European Water Framework Directive, therefore is not possible to assess whether other trace metals were under safe concentrations. Strontium was found in concentrations ranging from $500-800 \mu \mathrm{g} \mathrm{L}^{-1}$ which are lower than the ATSDR (2004) quality criteria levels set at $4000 \mu \mathrm{g} \mathrm{L} \mathrm{L}^{-1}$.

\subsection{Phytoplankton seasonal dominance}

Chlorophyll- $a$ concentrations showed large variation from the surface down to $30 \mathrm{~m}$ (Fig. 8), with the highest variation in summer 2007 (max. coefficient of variation [C.V] 46\% July 07) and the lowest in winter (13\% Jan
$2005,2006,2007)$. The maximum Chl- $a$ concentrations were measured in May and July $2006\left(60 \mu \mathrm{g} \mathrm{L}^{-1} ; 12 \mathrm{~m}\right.$ and $\left.63 \mu \mathrm{g} \mathrm{L}^{-1} ; 8 \mathrm{~m}\right)$. The mean Chl- $a$ concentrations (weighted by volume) in the upper water $(0-10 \mathrm{~m})$ showed large increases in the period just after the deep mixing of the water column during early 2005 and 2006 (Fig. 8). Significant relationships were found between Chl- $a$ (volume weighted mean) and Secchi depth (Spearman's $\rho=0.482, P<0.05$ ) and depth of maximum Chl- $a$ concentration and Secchi depth (Spearman's $\rho=$ $0.698, P<0.01)$.

The seasonal changes of phytoplankton group dominance followed to a certain extent that of a typical temperate eutrophic lake. In summer green algae dominated the superficial waters, passing from autumn through to winter there was a shift to cyanobacteria and then to diatoms in the spring. Throughout the study there was a considerable presence of the cyanobacterium Planktothrix (Oscillatoria) rubescens, often the dominant species in the deeper waters during summer, autumn and early winter. During periods of weak mixing the population of $P$. rubescens was normally confined to water of around $10{ }^{\circ} \mathrm{C}$ coinciding with the position of the metalimnion ( $10-15 \mathrm{~m}$ depth), however in winter and early spring the population was dispersed throughout the epilimnion. Prominent changes in seasonal dominance included a large shift from cyanobacteria to diatoms (March 2006; 65\% of total phytoplankton community) dominated by Asterionella formosa and less abundantly Fragilaria crotonensis, and Cyclotella sp. This change corresponds to a large increase in silica in the surface waters of around $300 \mu \mathrm{g} \mathrm{L}^{-1}$. 
Tab. 4. Summer 2005 chemical analysis data used as input for VMINTEQ calculations.

\begin{tabular}{|c|c|c|c|c|c|}
\hline \multirow[t]{2}{*}{ Parameter } & \multirow[t]{2}{*}{ Units } & \multicolumn{4}{|c|}{ Depth (m) } \\
\hline & & 0 & 10 & 140 & 160 \\
\hline Temperature & ${ }^{\circ} \mathrm{C}$ & 25.92 & 25.32 & 8.97 & 8.98 \\
\hline Redox & Mv & 36 & 45 & -279 & -279 \\
\hline $\mathrm{O}_{2}$ & $\left(\mathrm{mg} \mathrm{L}^{-1}\right)$ & 9.9 & 0.4 & 0.6 & 0.6 \\
\hline $\mathrm{O}_{2}$ & $(\%)$ & 126 & 5 & 5 & 5 \\
\hline $\mathrm{pH}$ & pH units & 8.79 & 8.69 & 7.06 & 7.11 \\
\hline Cond. $\left(20^{\circ} \mathrm{C}\right)$ & $\left(\mu \mathrm{S} \mathrm{cm}^{-1}\right)$ & 437 & 438 & 525 & 525 \\
\hline Tot. Alk. & $\left(\right.$ meq L $\left.{ }^{-1}\right)$ & 4.4 & 4.4 & 5.5 & 5.5 \\
\hline $\mathrm{Cl}$ & $\left(\mathrm{mg} \mathrm{L}^{-1}\right)$ & 19.8 & 19.6 & 18.8 & 19.2 \\
\hline $\mathrm{SO}_{4}$ & $\left(\mathrm{mg} \mathrm{L}^{-1}\right)$ & 7.2 & 7.1 & 5.2 & 5.1 \\
\hline $\mathrm{NO}_{3}-\mathrm{N}$ & $\left(\mu \mathrm{g} \mathrm{L}^{-1}\right)$ & 18 & 13 & 13 & 13 \\
\hline $\mathrm{NH}_{4}-\mathrm{N}$ & $\left(\mu \mathrm{g} \mathrm{L}^{-1}\right)$ & 6 & 50 & 1706 & 1790 \\
\hline $\mathrm{Ca}$ & $\left(\mathrm{mg} \mathrm{L}^{-1}\right)$ & 17.8 & 18.3 & 38.0 & 37.2 \\
\hline $\mathrm{Mg}$ & $\left(\mathrm{mg} \mathrm{L}^{-1}\right)$ & 16.8 & 16.4 & 17.0 & $16 ., 5$ \\
\hline $\mathrm{Na}$ & $\left(\mathrm{mg} \mathrm{L}^{-1}\right)$ & 31.3 & 30.7 & 30.3 & 29.8 \\
\hline $\mathrm{K}$ & $\left(\mathrm{mg} \mathrm{L}^{-1}\right)$ & 50.5 & 49.5 & 50.0 & 48.7 \\
\hline RP & $\left(\mu \mathrm{g} \mathrm{L}^{-1}\right)$ & 3 & 4 & 276 & 286 \\
\hline TP & $\left(\mu \mathrm{g} \mathrm{L}^{-1}\right)$ & 9 & 13 & 307 & 322 \\
\hline $\mathrm{TN}$ & $\left(\mu \mathrm{g} \mathrm{L}^{-1}\right)$ & 320 & 440 & 1940 & 1950 \\
\hline $\mathrm{Si}$ & $\left(\mathrm{mg} \mathrm{L}^{-1}\right)$ & 0.01 & 0 & 1.86 & 1.87 \\
\hline Al & $\left(\mu \mathrm{g} \mathrm{L}^{-1}\right)$ & 10 & 8 & 6 & 6 \\
\hline As & $\left(\mu \mathrm{g} \mathrm{L}^{-1}\right)$ & 1 & 1 & 2 & 2 \\
\hline B & $\left(\mu \mathrm{g} \mathrm{L}^{-1}\right)$ & 95 & 104 & 120 & 100 \\
\hline $\mathrm{Ba}$ & $\left(\mu \mathrm{g} \mathrm{L}^{-1}\right)$ & 11 & 11 & 20 & 23 \\
\hline $\mathrm{Cd}$ & $\left(\mu \mathrm{g} \mathrm{L}^{-1}\right)$ & 0 & 0 & 1 & 1 \\
\hline $\mathrm{Co}$ & $\left(\mu \mathrm{g} \mathrm{L}^{-1}\right)$ & 0 & 1 & 1 & 1 \\
\hline $\mathrm{Cr}$ & $\left(\mu \mathrm{g} \mathrm{L}^{-1}\right)$ & 0 & 0 & 0 & 0 \\
\hline $\mathrm{Cu}$ & $\left(\mu \mathrm{g} \mathrm{L}^{-1}\right)$ & 1 & 1 & 1 & 1 \\
\hline $\mathrm{Fe}$ & $\left(\mu \mathrm{g} \mathrm{L}^{-1}\right)$ & 3 & 2 & 78 & 57 \\
\hline $\mathrm{Li}$ & $\left(\mu \mathrm{g} \mathrm{L}^{-1}\right)$ & 7 & 7 & 7 & 8 \\
\hline $\mathrm{Mn}$ & $\left(\mu \mathrm{g} \mathrm{L}^{-1}\right)$ & 1 & 1 & 117 & 118 \\
\hline $\mathrm{Ni}$ & $\left(\mu \mathrm{g} \mathrm{L}^{-1}\right)$ & 1 & 1 & 1 & 2 \\
\hline $\mathrm{Pb}$ & $\left(\mu \mathrm{g} \mathrm{L}^{-1}\right)$ & 0 & 0 & 0 & 0 \\
\hline $\mathrm{Pt}$ & $\left(\mu \mathrm{g} \mathrm{L}^{-1}\right)$ & 0 & 0 & 0 & 0 \\
\hline $\mathrm{Se}$ & $\left(\mu \mathrm{g} \mathrm{L}^{-1}\right)$ & 2 & 2 & 0 & 0 \\
\hline $\mathrm{Sr}$ & $\left(\mu \mathrm{g} \mathrm{L}^{-1}\right)$ & 554 & 558 & 676 & 698 \\
\hline $\mathrm{Ti}$ & $\left(\mu \mathrm{g} \mathrm{L}^{-1}\right)$ & 0 & 0 & 0 & 0 \\
\hline V & $\left(\mu \mathrm{g} \mathrm{L}^{-1}\right)$ & 50 & 50 & 47 & 47 \\
\hline $\mathrm{Zn}$ & $\left(\mu \mathrm{g} \mathrm{L}^{-1}\right)$ & 2 & 1 & 2 & 3 \\
\hline
\end{tabular}

Tab. 5. Calcium species concentrations $\left(\mu \mathrm{Mol} \mathrm{L} \mathrm{L}^{-1}\right)$ as predicted by VMINTEQ

\begin{tabular}{lcccc}
\hline Ca species & \multicolumn{4}{c}{ Depth $(\mathrm{m})$} \\
\cline { 2 - 5 } & 0 & 10 & 140 & 160 \\
\hline $\mathrm{Ca}^{+2}$ & 27 & 339210 & 942 & 922 \\
$\mathrm{CaHCO}_{3}{ }^{+}$ & 6425 & 7915 & 5536 & 6091 \\
$\mathrm{CaCO}_{3}(\mathrm{aq})$ & 15031 & 17678 & 282 & 348 \\
$\mathrm{CaH}_{2} \mathrm{PO}_{4}^{+}$ & 0 & 0.01 & 68.97 & 57.02 \\
$\mathrm{CaHPO}_{4}(\mathrm{aq})$ & 2 & 3.3 & 887.2 & 823.5 \\
$\mathrm{CaNH}_{3}{ }^{+}$ & 0.02 & 0.26 & 8.64 & 9.96 \\
$\mathrm{CaNO}_{3}{ }^{+}$ & 0.19 & 0.17 & 5.23 & 0.51 \\
$\mathrm{CaOH}^{+}$ & 19.09 & 22.32 & 4 & 0.44 \\
$\mathrm{CaPO}_{4}{ }^{-}$ & 2.3 & 3.7 & 20.3 & 21.1 \\
$\mathrm{CaSeO}_{4}(\mathrm{aq})$ & 0.22 & 0.28 & & \\
$\mathrm{CaSO}_{4}(\mathrm{aq})$ & 2607 & 3260 & 46783 & 45352 \\
$\mathrm{Ca}\left(\mathrm{NH}_{3}\right)_{2}^{+2}$ & $7.07 \mathrm{E}-10$ & $6.01 \mathrm{E}-08$ & 8.64 & 9.96 \\
$\mathrm{CaCl}^{+}$ & 289 & 363 & 8463 & 8480 \\
$\mathrm{Ca}^{+}\left(\mathrm{NO}_{3}\right)_{2}$ & $4.78 \mathrm{E}-13$ & $3.18 \mathrm{E}-13$ & $8.31 \mathrm{E}-12$ & 0.513 \\
\hline
\end{tabular}




\section{Saturation index (Log IAP-Log Ks)}

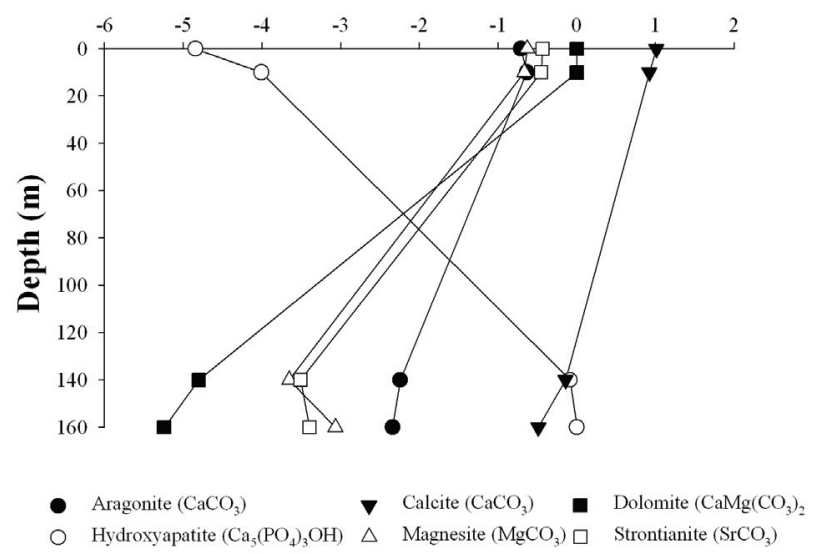

Fig. 7. Saturation index of species with potential to precipitate as function of depth as predicted by VMINTEQ. Other predicted species, in the model, not shown here are Diaspore - $\left.\mathrm{HAl}\left(\mathrm{H}_{2} \mathrm{O}\right)_{3}\right)$, Greenalite - $(\mathrm{Fe})_{2}-3 \mathrm{Si}_{2} \mathrm{O}_{5}(\mathrm{OH})_{4}$, Hercinite - FeAl.2 $\mathrm{H}_{2} \mathrm{O}$, amorphous $\mathrm{MnCO}_{3}$ and Rhodochrosite $\left(\mathrm{MnCO}_{3}\right)$.

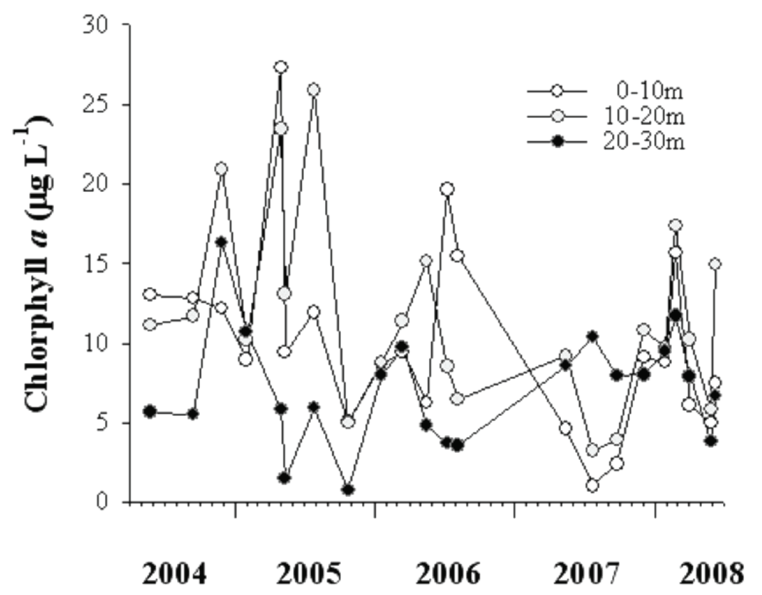

Fig. 8. Seasonal changes in epilimnion chlorophyll- $a$ concentration, data represented as volume weighted means for three depths $(0-$ $10,10-20,20-30 \mathrm{~m})$.

In the summer months green algae dominated the surface waters (up to $97 \%$ of the total community) made up of Mougeotia sp. Closterium aciculare and Closterium acutum var variabile (early summer) then mainly Mougeotia spp. (mid-summer). In the surface water during autumn 2007 there were large increases of the nitrogen fixing cyanobacteria Aphanizomenon sp. and to a lesser extent Anabaena spp. At the same time a large population of $P$. rubescens was found at $25 \mathrm{~m}$ depth. Visible surface accumulations of $P$. rubescens normally occurred around March at the leeward shores of the lake and discoloured the water red.

\section{DISCUSSION}

In the case of Lake Albano, the thermal profile close to the homothermy is normally not sufficient to permit the full overturn of the water, due to the large depth relative to the surface area and the acute cone shape of the lake basin (Fig. 1). The occurrence of full overturn in Lake Albano is a rare event indicated by the absence or trace oxygen level concentrations, the reducing conditions in the major part of the water column (elevated $\mathrm{NH}_{4}-\mathrm{N}, \mathrm{NO}_{3}-\mathrm{N}$ absence and sulphate depletion) and by previous paleolimnological studies (Guilizzoni \& Oldfield 1996). However, for two years during this study (2005 and 2006) full overturn events occurred and the possibility of future overturns at irregular intervals could be expected. Overturn events can cause the transport of non desirable elements, such as phosphorus, from the lower layers to the upper layers, resulting in high spring algal production.

The low sampling frequency did not permit a detailed description of the winter 2005-06 circulation event. However, the occurrence of a water mixing is clearly documented by the increase of oxygen in the hypolimnion observed from $25 / 10 / 05$ to $17 / 01 / 06$ and 15/03/06 (from zero to 2.2 and $3.7 \mathrm{mg} \mathrm{L}^{-1} \mathrm{O}_{2}$ ) and from 
the redistribution over the water column of $\mathrm{NH}_{4}-\mathrm{N}$, SRP, TP, RSi (Fig. 6), calcium and total alkalinity. The $\mathrm{O}_{2}$ concentration in the deepest water was soon depleted from the oxidation of ammonium, methane and other reducing substances, so that in July 2007 the $\mathrm{O}_{2}$ concentration below $70 \mathrm{~m}$ was zero. The second episode of re-oxygenation of the deepest waters was observed during August 2006 and July 2007, although the re-distribution of other chemical parameters was not found suggesting this could be an artefact of the infrequent sampling.

\subsection{Main factors affecting water chemistry}

Concerning water quality, one important characteristic of Lake Albano, is the small surface area of the emerged watershed $\left(3.57 \mathrm{~km}^{2}\right)$ when compared to lake surface area $\left(6.02 \mathrm{~km}^{2}\right)$. This aspect becomes more important when considering the lake volume $\left(464 \times 10^{6}\right.$ $\mathrm{m}^{3}$ ) resulting from a relatively small water supply with a very long theoretical water turnover period $(47.6 \mathrm{y})$. This aspect put emphasis on the role of groundwater flows that reach and feed the lake and that have reduced over time due to over extraction.

Past hydrological events connected with volcanic activity, such as water and mud overflowing the crater walls, were associated with large and highly energetic volumes of water (Funiciello et al. 2003). At present, it is predicted that there will be a continual decrease in lake volume and water quality. As already stated this phenomenon can have considerable impacts on the water quality and has been implicated in the increasing incidence of eutrophication of lakes (Matsui et al. 1995). Most of the nutrients and substances reaching the lake from the watershed or from atmospheric deposition can only leave the water column through sedimentation or else they remain in solution increasing the ion concentration due to evaporation processes. As pointed out here, the mixing process assumes an increasingly relevant role in the redistribution of ions and nutrients along the water column.

The chemical speciation modelling of Lake Albano water showed that calcite and dolomite could be oversaturated in the epilimnion during the spring and summer months. For calcite precipitation to occur there needs to be a prior supersaturation of $\mathrm{CaCO}_{3}$ minerals (past a critical concentration) and nucleation of crystal formation (Arp et al. 2001). During spring there was a large increase in the primary productivity of the lake and the associated increase in algal photosynthesis and cellular uptake of $\mathrm{CO}_{2}$ likely led to an increase in $\mathrm{pH}$ at the immediate cell surface. The uptake of $\mathrm{CO}_{2}$ and the increase in $\mathrm{pH}$ causes a shift in the carbonic acid equilibrium towards an increase in $\mathrm{CO}_{3}{ }^{2-}$ resulting in a very local, sharp increase in $\mathrm{CaCO}_{3}$ oversaturation (Stabel 1986; Kurz 2000; Dittrich \& Sibler 2005). This biological mediated concentrating of $\mathrm{CaCO}_{3}$ facilitates the nucleation of calcite crystals shown to occur on the sur- face of various algae at acidic groups of extracellular polymeric substances (Arp et al. 2001; Dittrich \& Obst 2004). The higher water temperatures during this period also cause a lower solubility of atmospheric $\mathrm{CO}_{2}$ into the lake, which further favours the precipitation of calcite. Temperature also affects ion diffusion velocity and in turn influencing the rates of calcite deposition and dissolution (Bisset et al. 2008).

In Lake Albano, there is a simultaneous reduction in the concentrations of alkalinity, $\mathrm{Ca}$ and $\mathrm{Chl}-a$ in the upper $20 \mathrm{~m}$ from spring to summer. This implies that the control of the cell surface microenvironment, with regard to $\mathrm{pH}$ and $\mathrm{CaCO}_{3}$ may be a controlling factor in the precipitation of calcite. As the epilmnion of the lake warms and calcite precipitation increases there is also a reduction in the viscosity of water leading an increase in sedimentation rates of particulate matter (Weilenmann et al. 1989). $\mathrm{CaCO}_{3}$ precipitation events can be rapid, taking as little as a couple of weeks (Dittrich \& Obst 2004) and most probably missed in Lake Albano because of the low frequency sampling.

The natural process of the co-precipitation of calcite and $\mathrm{P}$ has been utilised as a tool for the remediation of lake eutrophication (Dittrich \& Koschel 2002). However, elevated P levels have been shown to inhibit calcite precipitation (House 1987), and therefore is thought to be natural occurrence of mainly oligo-mesoeutrophic lakes. In Lake Albano it could be that the P taken up by the large spring phytoplankton population (mostly diatoms, see below) removes the $\mathrm{P}$ inhibition of calcite precipitation and provides more sites of nucleation provided by the increased biomass. From the Lake Albano data it is not known if the P levels are maintained at low concentrations by biological uptake or by co-precipitation processes as there is a concomitant decrease in Chl- $a$, TP and $\mathrm{Ca}$ from the epilimnion in summer compared to spring. To elucidate this would take a high resolution study of aqueous, sediment and cellular phosphorus chemistry combined with phytoplankton dynamics.

Part of the sinking calcite can be re-dissolved in the hypolimnion because of the lower $\mathrm{pH}$ values and oversaturation of $\mathrm{CO}_{2}$ due to organic matter degradation. Furthermore in Lake Albano sub-surface volcanic $\mathrm{CO}_{2}$ springs lower the $\mathrm{pH}$ creating conditions favourable for calcite solubilisation and the consequent release of previously adsorbed phosphorus. The increase of calcium and bicarbonate concentrations in the hypolimnion increases the density of the water. These aspects are shown by the variations of solute chemistry along the water column and from the chemistry of sediments (Lami et al. 1994).

The presence of large strontium concentrations and the potential precipitation of strontianite shown in figure 7 , as indicated by VMINTEQ speciation results, goes against the common thought that non-calcitic carbonates are only deposited evaporitically (Morse \& Mackenzie 
1990). However, extensive lacustrine deposits of strontianite do exist (Sonnenfeld 1984) and it has been shown that Sr-containing minerals can also be formed by the same biogenic mechanism as Ca-containing minerals (Thompson \& Ferris 1990; Thompson et al. 1990). In the epilimnion (and the metalimnion) of Lake Albano the large concentrations of cyanobacteria cells, if given the proper geochemical environment, could have an important role in the formation of strontianite (SchultzeLam \& Beveridge 1994).

\subsection{Speciation from modelling}

According to major cation concentration profiles presented above and because of the direct relation of $\mathrm{Ca}$ with alkalinity and conductivity, the modelling-results and discussion concentrated in $\mathrm{Ca}$ species. Table 5 shows the major $\mathrm{Ca}$ species in solution were associated to the carbonate system. Figure 7 shows SI values for minerals that had the potential to form or precipitate at the various depths based on VMINTEQ predictions. Model predictions showed that Aragonite and Calcite both $\mathrm{CaCO}_{3}$ species had the potential to precipitate in the superficial waters $(0-20 \mathrm{~m})$ followed by dissolution at deeper waters (Fig. 8). Dolomite, a different carbonated species binding $\mathrm{Ca}$ and $\mathrm{Mg}$, followed similar pattern. Hydroxypatite, which is a hydroxide form of calcium phosphate, appeared to be dissolved in shallow waters but precipitated in deep waters due to the combined effect of acidification and anoxic conditions prevailing at the bottom water layers.

The maintenance of the acute basin shape described by Martini et al. (1994) suggests that groundwater enters the lake with enough energy to re-suspend fine sediments. This energy may derive from the elevated water table to the west of the lake which is around 365 $\mathrm{m}$ a.s.l. compared to $290 \mathrm{~m}$ of the lake surface or from volcanically derived fluids and gases (Funiciello et al. 2003). The continual lake level lowering indicates that the water abstraction rate is greater than the recharge (Capelli et al. 1998). The run-off input is limited because of the small surface of the watershed. The reduced water input and the over-extraction of groundwater within the watershed makes Lake Albano extremely vulnerable to eutrophication processes.

In the eutrophication of lakes, $\mathrm{P}$ has often been implicated as the main causal factor (e.g., O.E.C.D. 1982), and therefore eliminating the sources of $P$ to the lake should be a priority in order to improve water quality of this increasingly diminishing resource. As shown in figure 7, some mineral phases such as Apatite or Hydroxyapatite can be important sinks mineralisation process for excess $\mathrm{P}$, in particular at depth (Ruttenberg \& Berner 1993). Other nutrient elements, such as $\mathrm{N}$ and to a lesser extent $\mathrm{Si}$, may also limit algal production during short seasonal periods (Klapper 2003). Unfortunately, these nutrients can rarely be regulated as they derive in mainly from atmospheric precipitation in the case of nitrogen (Bergström \& Jansson 2006), and from watershed weathering or recycling of silica (Schelske 1985).

\subsection{Seasonal changes in phytoplankton dominance}

In most deep, meromictic lakes the seasonal change in climate directs the progression of phytoplankton succession; two major variables driving this succession are changes in the stability of stratification and nutrient availability (Reynolds 1984). However, $\mathrm{CaCO}_{3}$ precipitation may also have a large effect during the transition from spring to summer (see above). After the large increase in epilimnion $\mathrm{N}$ and $\mathrm{P}$ (as well as $\mathrm{Si}$ ) from the full overturn there was no equivalent increase, over the seasonal average, in Chl- $a$ concentration. This unexpected outcome possibly derives from the low sampling frequency, the effects of which can be seen during May 2005 ; over nine days from $03 / 05 / 05$ to $12 / 05 / 05$ there was a 3-fold reduction in Chl- $a$ concentration between 0-10 m (27.3 to $\left.9.4 \mu \mathrm{g} \mathrm{L}{ }^{-1} \mathrm{Chl}-a\right)$.

Observations of seasonal changes in the phytoplankton community showed that in spring there was a general increase in diatoms, however in March 2006 there was an obvious proliferation/domination of the diatom Asterionella formosa. This proliferation coincided with the latter part of the deep mixing period and large input of nutrients, including silica, into the epilimnion from the hypolimnion. This colonial diatom has been described as an indicator of eutrophic and turbulent conditions and a good competitor for Si (Aleya 1992; Reynolds 1998). The observed epilimnetic silica concentrations of ca. $0.3 \mathrm{mg} \mathrm{L}^{-1}$ can be regarded as limiting for A. formosa growth (Lund 1964). When the samples were taken the population was already established, and so most of the silica in the epilimnion was already incorporated into the biomass. Therefore, it can be assumed that the RSi concentrations were non-limiting at the initial stages of the proliferation.

In summer, a reduction of mixing and nutrient concentrations plus the increase in water stability and light availability resulted in a dominance shift from diatoms to green algae (Wetzel 2001). The green algal community consisted of three principle species Mougeotia sp., Closterium aciculare and Closterium acutum var variabile in the upper part of the euphotic zone developing into a community dominated by Mougeotia sp. by midlate summer. A low sinking velocity and high resistance to grazing pressure are thought to give Mougeotia spp. a competitive advantage (Salmaso 2000). Additionally, an intense colouration of Mougeotia when stained to detect phosphatase activity using 5-bromo-4-chloro-3-indolyl phosphate nitro blue tetrazolium (BCIP-NBT; data not shown) suggests a capacity to use simple organic forms of P (Ellwood \& Whitton 2007) still present during the

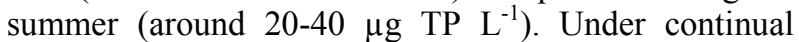
stratification and nutrient depletion (increased $\mathrm{N}$ limitation) the domination in the upper epilimnion shifted to 
nitrogen fixing cyanobacteria mainly Aphanizomenon. During 2006, the aqueous inorganic nitrogen status where accumulations of Aphanizomenon and Anabaena occurred was relatively rich in $\mathrm{NH}_{4}-\mathrm{N}$ compared to $\mathrm{NO}_{3}-\mathrm{N}$ (50 and $10 \mu \mathrm{g} \mathrm{L}^{-1} \mathrm{~N}$ at $10 \mathrm{~m}$ depth). It has been shown that Aphanizomenon growth rates are higher with $\mathrm{NH}_{4}$ rather than $\mathrm{N}_{2}$ and $\mathrm{NO}_{3}$ as an $\mathrm{N}$ source (Ward \& Wetzel 1980). Preferences for $\mathrm{NH}_{4}$ have also been reported for Anabaena circularis; $\mathrm{NH}_{4}$ was also shown to not inhibit di-nitrogen fixation (Ito \& Watanabe 1983). Given this, it could be that Aphanizomenon and Anabaena adjust their buoyancy to meet $\mathrm{N}$ demands in conjunction with $\mathrm{N}_{2}$ fixation. The dominance of nitrogen fixers may also be attributed to N-limitation indicated by the ratio of total inorganic N to SRP (TIN:SRP by mass) on the same sampling occasion of 4.8 at $0-10$ $\mathrm{m}$ and 7.2 at $20-30 \mathrm{~m}$ indicated possible $\mathrm{N}$ limitation (Redfield 1958).

In autumn, after the clearwater phase of the upper euphotic zone, there was an appearance of $P$. rubescens, although at depth (e.g, $20 \mathrm{~m} \mathrm{06/11/07)} \mathrm{there} \mathrm{was} \mathrm{still} \mathrm{a}$ metalimnetic population. This indicated the onset of mixing and the beginning of the displacement of this population by mixing forces. By winter the population was widely dispersed throughout the euphotic zone suggesting that control of vertical distribution during this period is mainly due to turbulent mixing rather than active buoyancy control (Dokulil \& Teubner 2000; Oliver \& Ganf 2000; Walsby et al. 2003). This generalised overview can show some changes from year to year due to changes in seasonal meteorological conditions which would be expected for a deep temperate lake (Round 1971; Sommer 1993).

The early-spring accumulations of $P$. rubescens were likely caused by nutrient-enrichment of the epilimnion during mixing and the low irradiance of the turbulent water leading to increased cell buoyancy pushing the cells toward the surface (Oliver \& Walsby 1984; Reynolds 1984). Reducing this buoyancy generally takes time and the extended period at the surface can lead to physiological damage and likely cell senescence by the high light intensities (Oliver \& Ganf 2000). As already stated above, $P$. rubescens has the potential to produce microcystins and it is likely that this cell damage leads to the release of microcystins into the lake, and possibly the groundwater where trace levels have already been measured (Messineo et al. 2006).

\section{CONCLUSIONS}

The study has highlighted essential aspects of the physical and chemical limnology of Lake Albano and linked them with the morphology, hydrology and volcanic nature of its aquifer and watershed basin. The conic form and the remarkable depth of the lake normally restrict complete winter mixing which prevents the oxygenation of hypolimnic waters during the period of thermal stratification. This oxygen deficit has been accentuated in the last decades by the deterioration of the lake's trophic status and the consequent increase of organic matter sedimentation. Surprisingly, this study showed full mixing events down to the bottom of the lake identified by the near homogenization along the water column of algal nutrients. The infusion of oxygenated waters into the hypolimnion were quickly consumed by the oxidation of reducing substances mainly $\mathrm{NH}_{4}$ and hydrogen sulphide compounds. The subsurface emissions of volcanic $\mathrm{CO}_{2}$ plays a fundamental part in the equilibrium of inorganic carbon, by lowering the $\mathrm{pH}$ and provoking partial resolubilisation of $\mathrm{CaCO}_{3}$ precipitates in the hypolimnion developed from epilimnion biological processes. The potential co-precipitation of calcite and phosphorus can result in a reduction of dissolved phosphorus from the epilimnion, but the dissolution of calcite in the hypolimnion means there is a release of $\mathrm{P}$, where it may be brought back in circulation after mixing. The full overturn of the lake during this study instils doubts of the validity of the past meromictic classification given to Lake Albano. However, if the lake goes through extended periods of meromixis any calcite and phosphorus entering into the monimolimnion (the deep undisturbed layer) is likely to remain there until another full mixing event occurs.

The declining volume of the lake combined with internal loading and continual external inputs of $\mathrm{N}$ and $\mathrm{P}$ are the most probable causal factors of toxic cyanobacterial blooms. These phenomena occur regularly for long periods in the year, in autumn then in late winter and spring. These blooms must be considered permanent or lasting at least until there is a cessation of external inputs and/or a reduction in water abstraction to allow a regain of lake volume. The small catchment size simplifies the identification of external nutrient inputs which most likely arise from surface runoff and municipal effluents that still discharge into the lake. Therefore, any attempt to recover and improve water quality in Lake Albano will need to consider, firstly, elimination of all external inputs of $\mathrm{P}$ into the lake and secondly, the re-naturalization of the hydrological budget of the lake at the watershed scale. Both these aspects must be preceded by in-depth studies of the main sources of $\mathrm{P}$ and the excessive water extraction for the realisation of an effective water use management strategy. Without making any mitigating measures the extent if the problems associated with Lake Albano will only accelerate with the decreasing volume of the lake.

Stopping the external $\mathrm{P}$ inputs will aid the recovery of the lake; however it will take some years before mesotrophy is attained due to slow water renewal rates and the storage of nutrients in the hypolimnion. Under these conditions, the use of techniques to shorten the recuperation time could be considered. Such techniques focus on increasing the precipitation rate of $\mathrm{P}$ and avoiding hypolimnetic solubilisation, for instance using aluminium hydroxide or other poly-electrolytes as floc- 
culants (Galvez-Cloutier et al. 2002). Positive effects could also derive from the oxygenation through the injection of oxygen gas to the deepest waters which can also reduce significantly the presence of $\mathrm{P}$ in the water column (Prepas et al. 1997; Klapper 2003).

\section{ACKNOWLEDGEMENTS}

We would like to thank Ente Regionale Parco dei Castelli Romani for the permission to sample Lake Albano and partial financial support, and the Polizia Provinciale, for use of their boat on sampling field trips. Suggestions of two anonymous reviewers greatly improved the paper.

\section{REFERENCES}

Agency for Toxic Substances and Disease Registry (ATSDR). 2004. Toxicological profile for Strontium. Atlanta, GA: U.S. Department of Health and Human Services, Public Health Service.

Aleya, L. 1992. The seasonal succession of phytoplankton in a eutrophic lake through the coupling of biochemical composition of particulates, metabolic parameters and environmental conditions. Arch. Hydrobiol., 124: 69-88.

Allison, J.D., D.S. Brown \& K.J. Novo-Gradac. 1991. MINTEQA2, A geochemical assessment model for environmental systems: Version 3 User's Manual. Env. Res. Lab., U.S. Environmental Protection Agency, Athens GA USA 1991: $11 \mathrm{pp}$.

Allison, J.D. \& D.S. Brown. 1995. MINTEQA2/PRODEFA2 a Geochemical Speciation Model and Interactive Preprocessor, Chemical Equilibrium and Reaction Models, Soil Sci. Soc. Am. J. Special Publication Number 42: 241-252.

A.P.H.A., A.W.W.A., W.E.F. 1992. Standard Methods for the examination of water and wastewater. Am. Publ. Health Ass., Washington.

A.P.H.A., A.W.W.A., W.E.F. 2005. Standard Methods for the examination of water and wastewater. (Method 3120 B). Am. Publ. Health Ass., Washington.

APAT, IRSA-CNR. 2003. Metodi analitici per le acque. Vol. 1\&2. IRSA-CNR: $1153 \mathrm{pp}$.

Arp, G., A. Reimer \& J. Reitner. 2001. Photosynthesis-induced biofilm calcification and calcium concentrations in Phanerozoic oceans. Science, 292: 1701-1704

Bazzanti, M. \& M. Seminara. 1995. Eutrophication in a deep, meromictic lake (Lake Albano, Central Italy): spatial-temporal patterns of profundal benthic community as a tool for assessing environmental stress in the hypolimnion. Limnologica, 25(1): 21-31.

Beaubien, S.E., G. Ciotoli \& S. Lombardi. 2003. Carbon dioxide and radon gas hazard in the Alban Hills area (Central Italy). J. Volcanol. Geotherm. Res., 123: 63-80.

Bergström, A.K. \& M. Jansson. 2006. Atmospheric nitrogen deposition has caused nitrogen enrichment and eutrophication of lakes in the northern hemisphere. Glob. Change Biol., 12(4): 635 - 643.

Bersani, P. \& V. Castellani. 2005. Considerations on water flow regulation in ancient time in the Alan Hills. Geologia, Tecnica \& Ambientale, 1: 59-90.

Bissett, A., A. Reimer, D. de Beer, F. Shiraishi \& G. Arp. 2008. Metabolic micro-environmental control by photosynthetic biofilms under changing macro-environmental temperature and $\mathrm{pH}$ conditions. Appl. Env. Microbiol., 74: 6306-6312

Bogialli, S., M. Bruno, R. Curini, A. di Corcia, C. Falani \& A. Lagan. 2006. Monitoring Algal Toxins in lake water by liquid chromatography tandem mass spectrometry. Env. Sci. Technol., 40: 2917-2923.

Briand, J.F., S. Jacquet, C. Bernard \& J.F. Humbert. 2003. Health hazards for terrestrial vertebrates from toxic cyanobacteria in surface water ecosystems. Vet. Res., 34(4): 361-377.

Calcara, M., S. Lombardi \& F. Quattrocchi. 1995. Geochemical monitoring for seismic surveillance. In: Trigila, R. (Ed.), The Volcano of the Alban Hills. Tipografia SGS, Rome: 221-243.

Cannicci, G. 1953. Su una eccezionale fioritura del Lago di Albano. Boll. Pesca Piscic. Idrobiol., 8: 221-233.

Capelli, G., A. Cecili, D. de Rita, G. Giordano \& R. Mazza. 1998. La conoscenza idrogeologica del territorio quale presupposto alla gestione delle risorse idriche: il caso dei Colli Albani. In: A.N.I.P.A. Uso e tutela delle acque sotterranee. Atti Giornata di Studio, Viterbo, 3 aprile 1998: 109-162.

Capelli, G., R. Mazza, G. Giordano, D. De Rita \& R. Salvati. 2000. The Colli Albano Volcano (Rome, Italy): equilibrium breakdown of a hydrological unit as a result of unplanned and undercontrolled over-exploitation. Hydrogéologie, 4: 63-70.

Carapezza, M.L., M. Lelli \& L. Tarchini. 2008. Geochemistry of the Albano and Nemi craters lakes in the volcanic district of Alban Hills (Rome, Italy). J. Volcanol. Geotherm. Res. Special Volume on Volcanic Lakes. Volume: 178 (2): 297-304.

Chiarabba, C., L. Malagnini \& A. Amato. 1994. Three dimensional velocity structure and earthquake relocation in the Alban Hills volcano, Central Italy. Bull. Seismol. Soc. Am., 84: 295-306.

Chiarabba, C., A. Amato \& P.T. Delaney. 1997. Crustal structure, evolution, and volcanic unrest of the Alban Hills, Central Italy. Bull. Volcanol., 59, pp. 161-170.

Chondrogianni, C., D. Ariztegui, P. Guilizzoni \& A. Lami. 1996. Lakes Albano and Nemi (Central Italy): an overview. Mem. Ist. ital. Idrobiol., 55: 17-22.

Cioni, R., M. Guidi., B. Raco, L. Marini \& B. Gambardella. 2003. Water chemistry of Lake Albano (Italy). J. Volcanol. Geotherm. Res., 120: 179-195.

De Agostini, G. 1898. Esplorazioni idrografiche nei laghi vulcanici della provincia di Roma. Boll. Soc. geogr. it., 77.

De Agostini, G. 1917. Atlante dei laghi italiani. De Agostini, Novara - Roma.

Dittrich, M. \& S. Sibler. 2005. Cell surface groups of two picocyanobacteria strains studied by zeta potential investigations, potentiometric titration, and infrared spectroscopy. J. Colloid Interf. Sci., 286 (2005): 487-495.

Dittrich, M. \& R. Koschel. 2002. Interactions between calcite precipitation (natural and artificial) and phosphorus cycle in the hard water lake. Hydrobiologia, 469: 49-57.

Dittrich, M. \& M. Obst. 2004. Are picoplankton responsible for calcite precipitation in lakes? Ambio, 33: 559-564.

Dokulil M.T. \& K. Teubner. 2000. Cyanobacteria dominance in lakes. Hydrobiologia, 438: 1-12.

Ellwood, N.T.W. \& B.A. Whitton. 2007. Importance of organic phosphate hydrolyzed in stalks of the lotic diatom Didymosphenia geminata and the possible impact of climate change. Hydrobiologia, 592: 121-133.

European Environmental Agency. 2008. http://themes.eea. europa.eu/Specific_media/water/indicators/WHS02,2004. 05, consulted in July 2008.

Ferree, M.A. \& R.D. Shannon. 2001. Evaluation of a second derivative UV/visible spectroscopy technique for nitrate and total nitrogen analysis of wastewater samples. Water Res., 35: 327-332.

Funiciello, R., G. Giordano \& D. De Rita. 2003. The Albano Maar Lake (Colli Albani volcano, Italy): recent volcanic activity and evidence of pre-Roman age catastrophic lahar events. J. Volcanol. Geotherm. Res., 123, 43-61. 
Funiciello, R., G. Giordano, D. de Rita, M.L. Carapezza \& F. Barberi. 2002. L'attività recente del cratere del Lago Albano di Castelgandolfo. Rend. Fis. Acc. Lincei, 9-13: 113143.

Galvez-Cloutier, R., S. Ize \& S. Arsenault. 2002. La Contamination des Lacs: manifestations et moyens de lutte contre l'eutrophisation. Vecteur Environnement, 35: 18-38.

Gentian, P, P. Donaghay, H. Yamazaki, R. Raine, B. Reguera \& T. Osborn. 2005. Harmful algal blooms in stratified environments. Oceanography, 18(2): 172-183.

Giordano, G., R. Mazza, A. Cecili, G. Capelli, D. de Rita, G. Bigi \& S. Rodani. 2000. Cities on Volcanoes: groundwater resources and management in a highly populated volcanic region. A GIS in the Colli Albani region, Rome, Italy. $J$. Nepal Geol. Soc., 22: 315-326.

Golterman, H.L., R.S. Clymo \& M.A.M. Ohnstand. 1978. Methods for physical and chemical analysis of fresh waters. I.B.P. Handbook No. 8, Blackwell, Oxford: 213 pp.

Gran, G. 1952. Determination of the equivalence point in potentiometric titration II. Analyst, 77: 661-671.

Guilizzoni, P., A. Lami, A. Marchetto, V. Jones, M. Manca \& R. Bettinetti. 2002. Palaeoproductivity and environmental changes during the Holocene in central Italy as recorded in two crater lakes (Albano and Nemi). Quaternary International, 88: 57-68.

Guilizzoni, P \& F. Oldfield. 1996. Palaeoenvironmental analysis of Italian crater lakes and Adriatic sediments (Paliclas). Mem. Ist. ital. Idrobiol. 55: 357-378.

House, W.A. 1987. Inhibition of calcite crystal growth by inorganic phosphate. J. Colloid Interface Sci., 119: 505-511.

ISO 11885 1996. Water quality. Determination of 33 elements by inductively coupled plasma atomic emission spectrometry.

Ito, O \& I. Watanabe. 1983. The relationships between combined nitrogen uptakes and nitrogen fixation in AzollaAnabaena symbiosis. New Phytol., 95: 647-654.

Karl, T.R. \& K.E. Trenberth. 2003. Modern climate change. Science, 302: 1719-1723.

Klapper. H. 2003 Technologies for Lake Restoration. J. Limnol., 62 (Suppl 1): 73-90.

Kurz, P. 2000. Calcium carbonate biomineralisation in freshwater picoplancton. Diploma thesis. EAWAG, Limnological Research Center, Kastanienbaum, Switzerland: $62 \mathrm{pp}$.

Lami, A., F. Niessen, P. Guilizzoni \& J. Masaferro. 1992. Preliminary results on palaeolimnology of crater Lake Albano (Latium, Italy). Verh. Internat. Ver. Limnol., 25 (2): 1117.

Lami, A., F. Niessen, P. Guilizzoni, J. Masaferro \& C. Belis. 1994. Paleolimnological studies of the eutrophication of volcanic Lake Albano (Central Italy). J. Palaeolimnol., 10: 181-197.

Langer, C.L. \& P.F. Hendrix. 1982. Evaluation of a persulphate digestion method for particulate nitrogen and phosphorus. Wat. Res., 16: 1451-1454.

Lund, J.W.G. 1964. Primary production and periodicity of phytoplankton. Verh. Internat. Verein. Limnol. 15: 37-56.

Margaritora, F.G., E. Stella \& O. Ferrara. 1988. Struttura e dinamica dello zooplancton di un lago vulcanico dell'Italia centrale (Lago Albano, Lazio). Riv. Idrobiol., 27: 131-147.

Margaritora, G.F. 1992. Limnology in Latium: the volcanic lakes. Mem. Ist. ital. Idrobiol., 50: 319-336.

Marinelli, O. 1894-95. Area, profondità ed altri elementi dei principali laghi italiani. Riv. Geogr. It., 1.

Marinelli, O. 1902. Escursione ai laghi laziali. Riv. Geograf. It., 2.

Marker, A.F. 1972. The use of acetone and methanol in the estimation of chlorophyll in the presence of phaeophytin. Freshwat. Biol., 2: 361-385.

Martini, M., L. Giannini, F. Prati, F. Tassi, B. Capaccioni \& Iozzelli, P. 1994. Chemical characters of crater lakes in the
Azores and Italy: the anomaly of Lake Albano. Geoch. Am. J., 28: 173-184.

Mastrantuono, L. 1990. Composition and distribution of the zoobenthos associated with submerged macrophytes in Lake Albano (Italy) and environmental quality in the littoral. Riv. Idrobiol., 29: 709-728.

Matsui, S., S. Ide \& M. Ando. 1995. Lakes and reservoirs: reflecting waters of sustainable use. Wat. Sci. Tech., 32(7): 221-224.

Medici, F. 2005. Laghi Albano e di Nemi: carenza idrica e alterazione della qualità delle acque. Geologia dell'Ambiente - Periodico trimestrale della Società Italiana di Geologia Ambientale - Anno XIII, 1: 8-11

Messineo, V., D. Mattei, S. Melchiorre, G. Salvatore, S. Bogialli, R. Salzano, R. Mazza, G. Capelli, \& M. Bruno. 2006. Microcystin diversity in a Planktothrix rubescens population from Lake Albano (Central Italy). Toxicon, 48: 160-174.

Morse, J.W. \& F.T. Mackenzie. 1990. Developments in sedimentology, Geochemistry of sedimentary carbonates. Vol. 48. Elsevier, Amsterdam.

Mosello, R., S. Arisci \& P. Bruni. 2004. Lake Bolsena (Central Italy): an updating study on its water chemistry. $J$. Limnol., 63: 1-12.

Murphy, J. \& J.P. Riley. 1962. A modified single solution method for the determination of phosphate in natural waters. Anal. Chim. Acta, 12: 162-176.

OECD. 1982. Eutrophication of Waters. Monitoring, Assessments and Control. OECD, Paris: $154 \mathrm{pp}$.

Oliver, R.L. \& A.E. Walsby. 1984. Direct evidence for the role of light-mediated gas vesicle collapse in the buoyancy regulation of Anabaena flos-aquae (cyanobacteria). Limnol. Oceanogr., 29: 879-886.

Oliver, R.L. \& G.G. Ganf. 2000. Freshwater Blooms. In: B.A. Whitton \& M. Potts.(Eds), The ecology of Cyanobacteria; their diversity in time and space. Kluwer Academic Publication, Dordrecht/ London/ Boston

Pagnotta, R., T. La Noce, M. Pettine \& A. Puddu. 1986. I laghi dell'Italia centrale: classificazione trofica ed analisi dei fattori che la influenzano. Atti A.I.O.L., 7: 385-396.

Paul, V.J. 2007. Global warming and cyanobacterial harmful algal blooms. In: Hudnell, H. Kenneth (Ed.), Cyanobacterial harmful algal blooms: state of the science and research needs. Adv. Exp. Med. Biol., 619: 225-243.

Pizzino, L., G. Galli, M. Guerra, C. Mancini, F. Quattrocchi \& P. Scarlato. 2000. 222Rn and $\mathrm{CO}_{2}$ in groundwater, soils and indoor throughout the Ciampino - Marino area (Alban Hills Volcano, Central Italy). Nat. Hazards, 27(3): 257-287.

Pomati F, S. Sacchi, C. Rossetti \& S. Giovannardi. 2000. The freshwater cyanobacterium Planktothrix sp. FP1: molecular identification and detection of paralytic shellfish poisoning toxins. J. Phycol., 36, 553-562.

Prepas, E.E., K.M. Field, T.P. Murphy, W.L. Johnson, J.M. Burke \& W.M. Tonn. 1997. Introduction to the Amisk Lake Project: oxygenation of a deep, eutrophic lake. Can. J. Fish. Aquat. Sci., 54: 2105-2110.

Provini, A., R. Marchetti \& G. Tartari. 1992. The Italian lakes: trophic status and remedial measures. In: Guilizzoni, P., G. Tartari \& G. Giussani (Eds), Limnology in Italy. Mem. Ist. ital. Idrobiol., 50: 147-169.

Redfield, A.C. 1958. The biological control of chemical factors in the environment. Am. Sci., 46: 205-221.

Reynolds, C. 1984. Phytoplankton periodicity: interactions of form, function and environmental variability. Freshwat. Biol., 14: 111-142.

Reynolds, C.S. 1998. What factors influence the species composition of phytoplankton in lakes of different trophic status? Hydrobiologia, 369/370: 11-26.

Rice, A. 2000. Rollover in volcanic crater lakes: a possible cause for Lake Nyos type disasters. J. Volcanol. Geotherm. Res., 97: 233-239. 
Round, F.E. 1971. The growth and succession of algal poulationsin freshwaters. Mitt. Internat. Verein. Limnol., 19: 70-99.

Ruttenberg, K.C., \& R.A. Berner. 1993, Authigenic apatite formation and burial in sediments from non-upwelling, continental margin environments. Geochim. Cosmochimica Acta, 57: 991-1007.

Salmaso, N. 2000. Factors affecting the seasonality and distribution of cyanobacteria and chlorophytes: a case study from the large lakes south of the Alps, with special reference to Lake Garda. Hydrobiologia, 438: 43-63.

Schelske, C.L. 1985. Biogeochemical silica mass balances in Lake Michigan and Lake Superior. Biogeochem., 1(3): 197-218.

Schultze-Lam S \& T.J. Beveridge. 1994, Nucleation of Celestite and Strontianite on a Cyanobacterial S-Layer. Appl. Environ. Microb., 60(2): 447-453.

Sigurdsson, H., I.D. Devine, F.M. Tchoua, T.S. Presser, M.K.W. Pringle \& W.C. Evans. 1987. Origin of the lethal gas burst from lake Monoun, Cameroon. J. Vol. Geotherm. Res., 31: 1-16.

Solórzano, L. 1969. Determination of ammonia in natural waters by the phenol-hypochlorite method. Limnol. Oceanogr., 14: 799-801.

Sommer, U. 1993. Disturbance-diversity relationships in two lakes of similar nutrient chemistry but contrasting disturbance regimes. Hydrobiologia, 249: 59-65.

Sonnenfeld, P. 1984. Brines and evaporites. Academic Press, Inc., Orlando, Florida.

Stabel, H.-H. 1986. Calcite precipitation in Lake Constance: Chemical equilibrium, sedimentation, and nucleation by algae. Limnol Oceanogr. 31(5): 1081-1093.

Stella, E. \& G. Argenti. 1953. Il Lago di Albano. Parte III: Le società bentoniche profonde. Boll. Pesca Piscic. Idrobiol., 8: 154-173.

Stella, E. \& V. Socciarelli. 1950. Il Lago di Albano. Parte I: La fisiografia e le società pelagiche. Boll. Pesca Piscic. Idrobiol., 4: 116-155.

Stumm, W. \& J.J. Morgan. 1981. Water chemistry: An introduction emphasizing chemical equilibria in natural waters. New York: Wiley-Interscience: $780 \mathrm{pp}$.

Thompson, J.B. \& F.G. Ferris. 1990. Cyanobacterial precipitation of gypsum, calcite, and magnesite from natural alkaline lake water. Geology, 18: 995-998.
Thompson, J.B., F.G. Ferris \& D.A. Smith. 1990. Geomicrobiology and sedimentology of the mixolimnion and chemocline in Fayetteville Green Lake, New York. Palaios, 5: 52-75.

Tuccimei, P., G. Giordano \& M. Tedeschi. 2006. CO2 release variations during the last 2000 years at the Colli Albani volcano (Roma, Italy) from speleothems studies. Earth Planet. Sci. Letters, 243: 449-462.

U.S. E.P.A. 1994. Determination of metal and trace elements in water and wastes by inductively coupled plasma atomic emission spectrometry. Method 200.7. U.S. E.P.A., Environmental Monitoring and Support Laboratory, Cincinnati, Ohio.

U.S. E.P.A. 1996. SW-846. Inductively coupled plasma atomic emission spectrometry. Method 6010B. U.S. E.P.A. Environmental Monitoring and Support Laboratory, Cincinnati, Ohio.

Valderrama, J.C. 1977. Methods used by the Hydrographic Department of the National Board of Fisheries. Goteborg, Sweden.

Valderrama, J.C. 1981. The simultaneous analysis of total nitrogen and total phosphorus in natural waters. Mar. Chem., 10: 109-122.

Varekamp, J.C., G.B. Pasternack \& G.L. Rowe Jr. 2000. Volcanic lake systematics II. Chemical constraints, J. Volcanol. Geotherm. Res., 97: 161-179.

Walsby, A.E., G. Ng, C. Dunn \& P.A. Davis. 2003. Comparison of the depth where Planktothrix rubescens stratifies and the depth where the daily insolation supports its neutral buoyancy. New Phytol., 162: 133-145.

Ward, A.K. \& R.G. Wetzel. 1980. Interactions of light and nitrogen source among planktonic blue-green algae. Arch. Hyrobiol., 90: 1-25.

Weilenman, U., C.R. O'Melia \& W. Stumm. 1989. Particle transport in lakes: models and measurements. Limnol. Oceanogr., 34(1): 1-18.

Wetzel, R.G. 2001. Limnology. Lake and River Ecosystems. Academic Press, San Diego: 1006 pp.

WHO. 2003. Cyanobacterial toxins: Microcystin-LR in drinking-water. Background document for preparation of WHO Guidelines for drinking-water quality. Geneva, World Health Organization (WHO/SDE/WSH/03.04/57).

Zhang, Y. 1996. Dynamics of $\mathrm{CO}_{2}$ driven lake eruptions. $\mathrm{Na}$ ture, 379: 57-59.

Received:October 2008

Accepted: April 2009 